\title{
İzmir Narlıdere'de Kentsel Dönüşüm Projesinin Uygulanmasında Gecekondu Maliklerinin Karşılaşabileceği Sorunlar
}

\author{
Ayça Uysal ${ }^{1}$ \\ ORCID: 0000-0003-4868-3739
}

\author{
Adile Arslan Avar ${ }^{2}$ \\ ORCID: 0000-0002-1548-7347
}

Öz

Çalışma, eleştirel kent teorisine dayanarak, İzmir'de neoliberal konut üretimi sürecinde yoksullarm konut sorununu ele almaktadır. Araştırmanın problemi, neoliberal konut üretiminin yarattı̆̆ı rant boşluğu baskısı ile yoksulların mülksüzleşmesidir. Çalışma metodolojik olarak çŏ̆ulcudur. Kurumsal, ikincil, mekânsal ve sayısal veriye, niceliksel ve niteliksel alan araştırmasına dayanarak, Narlıdere ilçesi İkinci İnönü Mahallesi gecekondu alanında yaşayan yoksullarm neoliberal konut üretimi karşısındaki durumlarmı incelemektedir. Çalışma alanı, lüks konut gelişimlerinin arasında sıkışıış bir gecekondu bölgesidir. Alan, Narlıdere ilçesinde bulunan Çatalkaya, Narlı ve Atatürk Mahallelerindeki gecekondu alanları ile birlikte 6306 sayılı Afet Riski Altındaki Alanların Dönüştürülmesi kanunu ile afet riskli alan ilan edilmiştir. Kentsel dönüşüm yapılması planlanmaktadır. Kentsel dönüşüm projesinin belirtilen amact, alanın mevcut sakinleri ile birlikte geliştirilmesidir. Ancak proje, mekansal dönüşüm ve pazar odaklıdır. Gecekondu alanında yaşayanların ekonomik, sosyal ve kültürel özelliklerine duyarsızdır. Araştırma bulguları ve alandaki güncel konut fiyatları ve doğrudan hanehalklarının gelir durumu dikkate alınarak yapılan konuta ekonomik erişilebilirlik (Housing Affordability Index) hesaplamaları, kentsel dönüşüm sürecinin gecekondularm temizlenmesi şeklinde gerçekleşeceğini ve gecekondu sakinlerinin sosyal, ekonomik ve mekansal sorunlar ile karşı karşıya kalabileceğini göstermektedir.

Anahtar Kelimeler: neoliberal konut üretimi, gecekondu, konut sorunu, finansallaşma, kentsel dönüşüm.

\footnotetext{
${ }^{1}$ Arş. Gör., Gaziantep Üniversitesi, E-mail: aycauysal@gantep.edu.tr

${ }^{2}$ Doç. Dr., İzmir Yüksek Teknoloji Enstitüsü, E-mail: adileavar@iyte.edu.tr

idealkent @ Kent Araştırmaları Dergisi (Journal of Urban Studies) 


\title{
Problems That Squatter Owners May Encounter after the Implementation of Urban Transformation in Narlıdere, İzmir
}

\author{
Ayça Uysal ${ }^{3}$ \\ ORCID: 0000-0003-4868-3739
}

\author{
Adile Arslan Avar 4 \\ ORCID: 0000-0002-1548-7347
}

\begin{abstract}
Based on the Critical Urban Theory, the study addresses the housing problem of the poor against neoliberal housing production in Izmir. The problem of research is the dispossession of the poor with the rent gap pressure created by neoliberal housing production. The situation of the poor living in the squatter area of the Narlidere, İkinci Inönü Neighborhood against the neoliberal housing production is examined. The study is methodologically pluralistic and it is based on institutional, spatial, and digital data, quantitative and qualitative field study. The squatter area is surrounded by luxury housing development and was declared as an area under disaster risk according to law number 6306. The transformation project which directly affects the squatter housing residents has been planning. The transformation project is market-based and focuses on spatial transformation. The research findings and Housing Affordability Index calculations which take the housing prices and household income into account show that the urban renewal process will result in slum clearance and residents of the squatters may encounter social, economic, and spatial problems.
\end{abstract}

Keywords: neoliberal housing production, squatter housing, housing question, financialization, urban transformation.

\footnotetext{
${ }^{3}$ Res. Asst., Gaziantep University, E-mail: aycauysal@gantep.edu.tr

${ }^{4}$ Assoc. Prof. Dr., İzmir Institute of Technology, E-mail: adileavar@iyte.edu.tr

idealkent @ Kent Araştırmaları Dergisi (Journal of Urban Studies) 


\section{Giriş}

Çalışma, son dönemin hâkim konut üretiminin nasıl ve hangi yollarla yoksulların konut sorununa neden olduğuna odaklanır. Çalışmanın amacı, İzmir, Narlıdere ilçesi İkinci İnönü Mahallesi'ndeki neoliberal konut üretimi baskısı altındaki yoksulların konut sorununu incelemektir. Çalışma kapsamındaki alan araştırması, İkinci İnönü, Atatürk, Narlı ve Çatalkaya Mahallelerini kapsayan kentsel dönüşüm projesinin yalnızca İkinci İnönü Mahallesine odaklanmaktadır.

İkinci İnönü Mahallesi'nde yerleşim 1950'lerin sonunda gecekondulaşma ile başlamış, 1970'lerde gecekondu sayısı artmıştır. 1980'lerde çıkan imar affı yasaları ve o dönem hâkim olan toplu konut üretimine rağmen, İzmir'e göçün artması ile alandaki kaçak yapılaşma 2000'li yılların sonuna kadar devam etmiştir. Gecekondu mahallesinin, lüks konut alanları ile çevrilmiş olmasıyla, rant boşluğu ortaya çıkmıştır. Önceleri de kentsel dönüşüm uygulanması tartışlan İkinci İnönü Mahallesi gecekondu alanı, 2012 senesinde çkan 6306 sayılı Afet Riski Altındaki Alanların Dönüştürülmesi Kanunu ile neoliberal konut üretiminin hedefi haline gelmiştir. Kuyucu (2017)'nun belirttiği gibi, 6306 sayılı yasanın amacı afet riski altındaki alanların hızlı bir şekilde dönüştürülmesi olmasına rağmen, yasa, kentsel alandaki sermaye birikiminin önemli bir aracıdır. Saha çalışması bulgularımız ve konuta ekonomik erişilebilirlik (Housing Affordability Index-HAI) hesaplamaları, İkinci İnönü Mahallesi gecekondu sakinlerini bu kanuna dayalı olarak 2018 yılında bir konut üreticisi şirket tarafından önerilen kentsel dönüşüm projesinin uygulanması halinde, öngörülen kredi geri ödeme koşullarını gecekondu maliklerinin karşılamalarının mümkün olmayacağını göstermektedir. Ancak hazırlanmakta olan yeni imar planının bu mahalle için neler getireceği ve onaylanacak imar planı uyarınca nasıl bir dönüşüm projesinin uygulanacağı, 6306 sayılı kanunda öngörülen süreçler uyarınca henüz belirlenmediğinden, bu makalenin son bölümünde yer alan "Konuta Ekonomik Erişilebilirlik" çalışması, 2018 yılında bir konut üreticisi şirket tarafından Narlıdere Belediyesine önerilmiş olan bir projenin olası sonuçları olarak değerlendirilmelidir. Diğer taraftan 6306 sayılı yasa uyarınca gerçekleştirilen dönüşüm projelerinde tapusu bulunan gecekondu sahiplerinin görüşlerinin ve çoğunluğunun rızalarının alınmasının gerekli olduğu bilinmektedir.

Türkiye'de neoliberalleşme, 1980'lerdeki yapısal uyum programları ile başlamıştır. 1960'lardan 1980'li yılların ortalarına kadar, hazine, kamu veya 
devlet arazilerine inşa edilen gecekondular, işçiler ve kırdan kente göçen yoksulların konut sorunu için düşük maliyetli bir çözüm olarak görülmüştür. Bu dönem, gecekondu konut alanları devletin 'yeniden dağıtım aracı' olmuştur (Demirtaş-Milz, 2013, s. 693; Türkün, 2014; Türkün, 2015). Kentsel politikalarda neoliberal dönüş 1990'larda ortaya çıkmıştır. Neoliberal kentsel yeniden yapılanma, önce İstanbul'da, arkasından diğer metropollerde yoksulların konut alanlarına, gecekondulara yönelmiştir. Neoliberal kentleşmenin en önemli aracı, kentsel rantı yüksek gecekondu alanlarında kentsel dönüşüm projeleriyle konut üretimidir. Gecekondu alanları bu sayede konut piyasasına eklemlenmiştir. Konut ise, metalaşma ve finansallaşma yolu ile sermaye döngüsüne dâhil edilmiştir. Türkün $(2014,2015)$, İstanbul'un altı mahallesinde, yoksulların konut alanlarının devlet eli ile soylulaştırmaya ve mülksüzleştirme yolu ile birikime maruz kaldığını ayrıntılı bir şekilde gösterir.

Son yirmi yıldır hız kazanan neoliberalleşme, kentlerde pazar odaklı mekân üretimine dayanmaktadır. Kuyucu (2017), 2001 ve 2008 senelerindeki iki krizin kentsel politika ve emlak piyasası düzenlemeleri üzerindeki etkilerini göstermiştir. 2008 krizini, önemli kurumsal yeniden yapılanmalar ve kentsel arazi ve konut piyasasındaki düzenlemeler izlemiş̧ir. Paradoksal görünmesine rağmen, ilk olarak âdem-i merkeziyetçilik ve ardından yeniden merkezileşme ile kurumsal yeniden yapılanma ve kentsel arazi ve konut piyasası düzenlemeleri, Türkiye'deki ekonomik krizleri aşmaya yöneliktir. Konut üretimi, 2001'den bu yana Türkiye'deki krizlerin aşılmasında önemlidir (Kuyucu ve Ünsal, 2010, s. 1479; Kuyucu, 2017).

\section{Yöntem}

Bu çalışma 2019 yılında tamamlanan ve savunulan yüksek lisans tezine dayanmaktadır. Birinci bölümde, neoliberal kentleşme ve konut üretimi, Türkiye'de neoliberal politikalar, kentsel dönüşüm ve İzmir'de konut üretimi literatüre dayanarak incelenmektedir. İkinci bölümde ise, İkinci İnönü Mahallesi'nde yürütülen saha çalışmasının bulgularına dayanarak, İzmir' de konutun finansallaşması, neoliberal politikalar altında konut üretimi, gecekondu sakinlerinin hâkim konut üretimi karşısındaki durumu anlatılmaktadır.

Saha çalışması, niteliksel ve niceliksel ampirik araştırma tekniklerine dayanmaktadır. Mekânsal gelişme, mahalle birimleri, gecekondu sakinlerinin sosyoekonomik özellikleri, gelir düzeyi, mülk sahipliği ve gecekonduların yapısal özellikleri, kentsel dönüşüm projesi ile ilgili bilgi ve tercihleri ile ilgili birincil veriler, odak grubu ve yüz yüze derin görüşmeler ve anketler yoluyla toplanmıştır. İkinci İnönü Mahallesi'ne odaklanılan alan araştırmasında 622 
adet gecekondunun bulunduğu alanda 60 adet anket yapılmıştır. Mekânsal düzenlemeler, mekânsal gelişme ve imar durumu ilgili veriler Narlıdere ve Büyükşehir Belediyesi ile ilgili kurumlardan elde edilmiştir. Ayrıca, gecekondu sakinlerinin kentsel dönüşüm projesi karşısındaki durumunu tahmin etmek amacıyla, konuta ekonomik erişilebilirlik endeksi (HAI) hesaplanmıştır. Çalışmada görüleceği gibi, çoğunluğu düzensiz gelire sahip, aralarında asgari ücretin altında geliri olanların bulunduğu gecekondu sakinlerinin neredeyse hiçbiri alanda yapılması planlanan kentsel dönüşüm projesinden geri ödemeler karşllığında konut sahibi olamayacaktır.

\section{Neoliberal Politikaların Konut Üretimine Etkisi}

Neoliberalizm, 1970 sonrası dönemi yöneten ekonomik, politik, kurumsal ve ideolojik bir yapılanmadır. Tanımlayıcı özellikleri, özelleştirme, devletin kamu hizmetlerinden çekilerek bu alanların 'serbestleştirilmesi' ve piyasaya tabi ekonomik düzenlemedir (Brenner ve Theodore, 2002; Harvey, 2005; Jessop, 2002; Mccarthy, 2004; Peck ve Tickell, 2002). Harvey (2006) 'e göre, neoliberalizmin dört temel bileşeni özelleştirme, finansallaşma, krizlerin yönetimi ve devletin yeniden dağıtım politikalarıdır.

Neoliberalizm, sermaye birikimi amaciyla spekülatif finansal araçlarla spekülatif mekânsal gelişmeyi destekler (Brenner, vd., 2010, s. 329-330). Kar ve piyasa odaklı birikim, 'mülksüzleştirme yoluyla birikimdir' (Harvey, 2006). Kentsel sermaye birikimi arazi geliştirme ile metalaşmış arsa ve büyük bölümü konut olan bina üretimine dayanır. Neoliberal politikalar altında ekonomik ve kentsel yeniden yapılanma ile konut finansal bir araç haline gelmiştir. Baskın özel sektör ve sermaye odaklı üretim, konut üretiminin sektöre dönüşmesine neden olmuştur (Çelik ve Gough, 2014; Marcuse ve Madden, 2016). Finansallaşan ve özelleştirilmiş konut sektörü ise, küresel ekonomiye daha fazla eklemlenmiştir (Forrest, 2008). Buna bağlı olarak, konut fiyatları ve konuta olan talep artmıştır. Yaşam alanlarının ödeme gücüne göre paylaşıldığı bir düzende yoksullar, sosyal, ekonomik ve mekansal olarak dışlanmakta, kent dişına itilmektedir (Marcuse ve Madden, 2016).

Spekülatif kentleşmede yatırımlar, kentsel rantın en yüksek olduğu alanlara yoğunlaşmaktadır (Goldman, 2010; Mayer, 2009, s. 367). Kent içinde yüksek ranta sahip alanların arasına sıkışmış yoksulun yaşam alanları, gecekondu bölgeleri yüksek kentsel rant potansiyeline sahiptir. Bu alanlardaki kentsel dönüşüm projeleri, yüksek rant elde etmenin bir aracıdır. Bu projelerle gecekondular temizlenir, kentsel büyüme ve rant amaçlı yatırımlara alan yaratılır. Yoksul haklarını dışlayan konut politikaları, yoksulların yerinden 
edilme, dışlanma, mülksüzleştirilmesiyle sonuçlanır (Fraser ve Kick, 2014). Ancak Türkiye'de 6306 sayılı kanun uyarınca, gecekondu ve ruhsatlı konutlarda mülk sahiplerinin bilgilendirilmesi ve çoğunluğunun onayı gerektiğinden, bugüne kadar ilan edilen "riskli alanların" ancak \%15 kadarında anlaşma sağlanarak uygulama başlayabilmiştir.

\section{Türkiye'de Konut Gelişimi, Kentsel Dönüşüm ve Yoksullar}

Türkiye'de kentleşme, 1950'li yıllarda kırdan kente göçenlerin 'yasal olmayan' yerleşimleriyle gelişmiştir. Kırdan kentsel alanlara göç eden nüfus, devlet ve sermayenin gereken kentsel, toplumsal altyapıyı sağlamamış olması nedeniyle, konut sorununu, kent çeperlerine, hazine arazilerine veya özel arazilere gecekondu inşa ederek çözmüştür (Ataöv ve Osmay, 2007, s. 62; Demirtaş-Milz, 2013, s. 693; Özdemir, 2011, s. 1102). 1960'larda ise, beş yıllık kalkınma planlarında gecekondu alanlarının fiziksel koşullarının iyileştirilmesi hedeflenmiştir. 1970'lerde devletin gecekonduya yaklaşımı belirgin şekilde değişmiştir. Gecekondu alanları kentsel yatırım alanı olarak tanımlanmış, gecekondu ticarileşmeye ve yatırım aracına dönüşmeye başlamıştır. Gecekonduların yüksek katlı apartmanlara ve bazı meslek kuruluşları ve bankaların desteği ile toplu konutlara dönüşümü başlamıştır. Gecekondu konutlarının pazar aracı haline gelmesi kentlerin sosyo-ekonomik değişimini de etkilemiştir. Ticarileşme ile artan gecekondu üretimine, yasadışı bireysel veya örgütlü aktörler de dahil olmuştur. Aynı zamanda gecekondularda, kiralık mülk sahipliği ortaya çıkmıştır. (Ataöv ve Osmay,2007, s. 62-65).

1980'lerden sonra özelleştirmeler, serbestleşme ve yasal düzenlemelerle konut, sermaye birikimine dahil olmuştur. Özellikle, 1980'li yıllardaki imar afları ve 1990 sonrası kentsel dönüşüm projeleri neoliberal kentleşmenin araçları haline gelmiştir. Bu dönem, 1982 tarihli Türkiye Cumhuriyeti Anayasası'nın da desteği ile toplu konut üretimi artmıştır. Kooperatifler ve belediyeler tarafından üretilen toplu konutlar, gecekondu sorununu çözmek yerine, kar odaklı bir şekilde orta ve üst gelir grubuna hitap etmiştir (Karasu, 2005, s. 60). 1984 yılında, huzlı ve plansız kentleşmeyi azaltmak amacı ile TOKİ, aynı zamanda, 2985 sayılı Toplu Konut Kanunu ile konut fonu kurulmuştur. TOKİ ve kendi fonunun kurulması, devletin konut destekleme girişimi sayılsa da, inşaat süreleri, maliyetler ve yapı kullanma izinleri açısından uygulamada dezavantajlar ortaya çıkmıştır (Özdemir, 2011, s. 1103).

Bu dönemin kentsel politikalarının önemli bir yasal dayanağı, imar aflar1dır. 1983 yılındaki 2805 sayılı ilk İmar Affı Yasası yasal olmayan binaların yıkımını gerektirmiştir. 1984 yılında kabul edilen 2981 sayılı ikinci İmar Affı 
Yasası, mevcut gecekonduların yasallaştırılmasını ve gecekondu sahiplerine tapu senedi verilmesini taahhüt etmiştir. 1986'da yürürlüğe giren 3290 sayılı İmar Affı Yasası ise, gecekondu sahiplerinin tapu almalarına imkan vermiştir. İmar affı yasaları bir yandan niteliksiz ve kaçak yapıları yasallaştırmış; diğer yandan dolaylı olarak gecekondu üretimini teşvik etmiştir. Dahası, gecekondu alanlarında yüksek katlı blokların inşasına izin verilmesi, gecekonduyu metalaşma sürecine dahil etmiştir. Aynı zamanda bu, devletin gecekonduların ticarileşmesini desteklediği anlamına gelir (Demirtaş-Milz, 2013, s. 696; Karasu, 2005, s. 83; Özdemir vd., 2005, s. 41).

Özelleştirmelerin öne çıtığ 1990'larda, konut üretiminin aktörleri, müteahhitler, küçük ve orta ölçekli inşaat firmaları, yerel yönetimler ve merkezi yönetimdir (Özdemir, 2011, s. 1102). Kentsel dönüşüm projeleri bu dönem, bir yandan Türkiye'nin en önemli kentsel gelişme stratejisi (Demirtaş-Milz, 2013), diğer yandan küresel kapitalist süreçler için rant ve sermaye birikiminin aracı haline gelmiştir (Erman, 2016). Kent çeperlerindeki gecekondu alanlarının dönüşümü ile orta gelir grubunun konut ihtiyacını karşılamak üzere toplu konutlar; kent merkezlerinde ise, üst gelir grubunun talebine cevap veren gökdelenler, lüks konutlar ve büyük iş merkezleri inşa edilmiştir. Kentlerin mekansal dokusu köklü bir biçimde değişirken, mülksüzleştirilen ve yerinden edilen gecekondu halkı bu kez yeni alanlarda gecekondularını inşa etmiştir (Ataöv, Osmay, 2007, s. 68; Özdemir vd., 2005).

Avrupa Birliğine uyum süreci, 2000'li yılların gelişme stratejilerinde belirleyici olmuştur (Ataöv ve Osmay, 2007, s. 68). Konut sektörünü, neoliberal politikalar ve spekülatif kentleşme yönlendirmiştir. Üretim ve kurumlar özelleştirilmiş; konut üretimi pazar odaklı hale gelmiştir (Kuyucu ve Ünsal, 2010, s. 1479). Bu doğrultuda, önemli yasal düzenleme ve değişiklikler yapılmıştır. Kentsel rantın yüksek olduğu alanlarda, kentsel dönüşüm projeleriyle lüks konut, rezidanslar ve gökdelenler inşa etmek için, yeni alanlar yaratılmıştır. 2000'li yıllarda önemli sayıda yapı üretilmiştir (Waite, 2016, s. 80). Ortaya ç1kan konut alanları toplumsal, ekonomik ve çevresel olarak sürdürülebilir değildir. 2007'de kabul edilen 5582 sayılı Konut Finansmanı Sistemine İlişkin Çeşitli Kanunlarda Değişiklik Yapılması Hakkında Kanun ile ipotek sistemi yeniden düzenlenmiştir ve konut, piyasada bir yatırım aracı haline gelmiştir. Konut sektöründe kapitalist ilişkilerin kurulması, ipotek sisteminin uygulanması, inşaat sektörünün ekonomik büyüme için öncelikli hale getirilmesi devlet düzenlemeleri ile sağlanmıştır (Adaman, 2017, s. 36). 2000'li yıllarda, yeni sermaye gruplarının ortaya çıması ile kentsel ranttan alınan pay dengeleri 
değişmiştir. Özel sektörün kentsel mekansal süreçlere hakim olması, kentsel sermayenin dağıtılmasını spekülatif hale getirmiştir.

Konut üretiminde 2000'li yıllardaki özel sektör hakimiyeti, yasal düzenlemeler ve yönetmeliklerin de desteği ile halen devam etmektedir. Kentsel dönüşümün en önemli aracı olan 2012' de yayınlanan “6306 Sayılı Afet Riski Altındaki Alanların Dönüştürülmesi Kanunu" kentsel gelişmenin de aracı haline gelmiştir. Yasanın amacı, afet riski altındaki alanlarda iyileştirme ve yenileme ile ilgili usul ve esasları belirlemektir (Resmi Gazete, 31 Mayıs 2012; Genç, 2014; Waite, 2016). Çevre ve Şehircilik Bakanlığı ve TOKİ, yasanın uygulanmasında yetki sahibidir. Bakanlık ayrıca, kentsel dönüşüm projeleri için, belediyeleri, TOKİ'yi veya özel şirketleri proje hazırlanması konusunda yetkilendirebilir. Bakanlık, riskli yapılar ve rezerv yapı alanları ile ilgili her türlü plan, proje, imar düzenlemesinden, arsa değerlerinin belirlenmesi, kamu-özel sektör ortaklıkları kurulması, binaların tespit, tahliye ve yıkım işlerine kadar geniş bir yetki alanına sahiptir. Kanunda, riskli yapıların belli bir sürede proje (yapı) sahipleri tarafından yıktırılması, bu yapılmadığında yapıların Çevre ve Şehircilik Bakanlığı tarafından yıktırılması öngörülmüştür. Yasaya göre, proje alanının mevcut sakinleri ve mülk sahipleri ile anlaşmaya varılması önceliklidir (Genç, 2014). Bu kurumsal ve yasal düzenlemeler bağlamında kentsel dönüşüm projeleri, gecekondu alanları da dahil, kentsel ve kentsel olmayan alanların özelleştirilmesi ve piyasalaştırılmasına yönelik etkin araçlardır. Belirtilmelidir ki, özel ve kamu aktörleri, gecekondu alanlarının hızlı ve etkin şekilde özelleştirilmesi ve dönüşümü için, enformel ilişkileri ve yasal açıkları da kullanmaktadır (Atasoy, 2017, s. 659; Demirtaş-Milz, 2013). Yüksek kentsel rant alanları arasına sıkışmış gecekondu alanları, oluşan rant boşluğu nedeniyle önemlidir. Türkiye'de kentsel dönüşüm projeleri bir rant aracı haline gelmiştir. Gecekondu alanlarında uygulanan kentsel dönüşüm projeleri gecekonduların temizlenmesi; yoksulların yerinden edilmesi ile sonuçlanmaktadır.

\section{İzmir'de Konut Üretimi}

İzmir'in kentleşme sürecinde de, Türkiye'deki diğer metropollerdeki gibi, 1950'lerden başlayarak, göç ve gecekondu gelişimi önemlidir. Ancak, diğer kentlerden farklı olarak, yine 1950'lerden bu yana kıyılarda ikincil konut ve İzmir Körfezi etrafında yüksek yoğunluklu lüks konut gelişimi de sürmektedir (Tekeli, 2009). 1980'lerde, neoliberal politikalara paralel yasal ve kurumsal yeniden düzenlemelerle İzmir'de kent çeperindeki özelleştirilen hazine ve kamu arazilerinde çok sayıda toplu konut inşa edilmiştir. 1985-1998 yılları 
arasında yürürlüğe giren imar yasaları ardından gecekondular ve yasadışı konut alanları için imar planları yapılmış, ancak gecekondu sakinlerinin fiziksel ve toplumsal koşullarına uygun, yeterli konut üretilmemiştir. Gecekondu alanlarında uygulanan iyileştirme planları da gecekondu sorunlarına kalıcı çözüm getirmemiştir. Ayrıca imar afları ve planlar, öncelikle mülkiyet sorununu çözmeye yöneliktir (Özdemir vd., 2005, s. 72). 1990'larda da gecekondu sorununa çözüm için, yerel yönetimler, kooperatifler, Emlak Bankası ve TOKİ kamu arazilerinde toplu konutlar üretmiştir. İmar afları ve imar planlarının ardından, konut piyasasına giremeyen yoksullar, yeni alanlarda gecekondu inşa etmiş; 2000'lerde de yasadışı konut ve gecekondu gelişimi devam etmiştir (Arslan, 2013, s. 93; Özdemir vd., 2005, s. 64).

Sermayenin İzmir'in kentleşme sürecindeki yoğunluğu gayrimenkul sektörüne yapılan özel yatırımlarla artmıştır. 1990'lı yılların ortalarından itibaren büyük ölçekli şirketler konut piyasasına girmiştir (Özdemir vd., 2005, s. 59). 2000'li yıllarda İzmir' de kentsel gelişme, neoliberal politikalarla yeni sermaye birikim rejimine tabi hale gelmiştir. Konut üretiminde özel sermaye ve özellikle 2000'li yıllardan sonra TOKİ'nin de etkin rol üstlendiği toplu konut projeleri hakimdir (Eraydın vd., 2013, s. 104).

Son dönemde İzmir'de konut üretiminde kentsel dönüşüm uygulamaları önemli yer tutmaktadır. İzmir' de Büyükşehir Belediyesince, kentsel dönüşümün, Türkiye'nin diğer kentlerinden farklı olarak, kentlinin sosyal hayat kalitesini de iyileştirmek adına katılımcılık ve sürdürülebilirlik kavramları ile birlikte planlandığı öne sürülmektedir. Kentsel dönüşümün temel amacı, "Metropoliten alanda yapılı çevrenin iyileştirilmesi"dir. "İzmir Modeli" çerçevesinde tanımlanan kentsel gelişme stratejilerine göre, "katılımcılık ve yönetişim ile hakça ve şeffaf bir şekilde yürütülen kentsel dönüşüm süreci"nin ekonomik ve sosyal yapının olumsuz etkilenmesi minimum seviyede olacak şekilde sonuçlanması hedeflenmektedir. İzmir Büyükşehir Belediyesinin \%100 uzlaşmaya ve yerinde dönüşüme dayanan bir kentsel dönüşüm yaklaşımı benimsediği, projelerde aktif bir rol üstlendiği vurgulanmaktadır (Yetişkul, 2018, s. 60-64).

Belirtilmelidir ki, İzmir Modeli kapsamında oluşturulan kentsel dönüşüm yaklaşımı, 2005 senesinde kabul edilen 5393 sayılı yasanın 73. maddesine göre yürütülmektedir. Bu yasaya göre yerel yönetimler kentsel dönüşüm ile ilgili geniş yetki sahibidir (Yetişkul, 2018, s. 72). Son dönemde ise, Türkiye'deki kentsel dönüşüm uygulamalarının yetkisi 2012 senesinde kabul edilen 6306 sayılı Afet Yasası olarak bilinen "Afet Riski Altındaki Alanların Dönüştürülmesi Kanunu” ile Çevre ve Şehircilik Bakanlığı'na geçmiştir. Bu 
yasaya göre İzmir'de Menemen, Narlıdere, Buca, Kemalpaşa, Gaziemir, Bayındır, Torbalı, Karabağlar, Konak, Karşıyaka ve Bayraklı ilçelerinde kentsel dönüşüm alanları ilan edilmiştir. Yanı sıra, parsel ölçeğinde binaların yıkılarak yenilenmesi de artmıştır (Yetişkul, 2018, s. 73; Zengin Çelik ve Çilingir, 2017).

İzmir'de, yukarıda işaret edilen "İzmir Modeli" çerçevesinde kentsel dönüşüm yaklaşımı, Türkiye'deki diğer kentlerde yürütülen kentsel dönüşüm uygulamalarından farklı olsa da yoksulların kent çeperlerine doğru itilmesi ile sonuçlanmıştır. Örneğin, kentteki en önemli ve tamamlanmış dönüşüm projelerinden olan Kadifekale Kentsel Dönüşüm Projesi, "heyelan riski" nedeniyle "zorunlu bir teknik müdahale" olarak tanımlanmış; alanda yaşayanlar kentsel dönüşüm projesi kapsamında İzmir Büyükşehir Belediyesi ile yapılan uzlaşma ile kent merkezinden, çeperdeki Uzundere TOKİ konutlarına taşınmışlardır. Diğer yandan, Kadifekale'de heyelan riskli alanda olduğu için yıkılan gecekonduların \%96'sı tapusuz, çoğunun da tapu tahsis belgeleri vardır. Tapu tahsis belgesi sahibi olanlar, "heyelan riskli alanda" oldukları için, idare mahkemesi kararıyla, 1980'lerdeki imar aflarından yararlanamamışlar ve tapu tahsis belgeleri geçersiz hale gelmiştir (Saraçoğlu ve Demirtaş-Milz, 2014).

Kısaca özetlemek gerekirse, İzmir'de farklı idareler tarafından önerilen ve farklı yasalara dayanan dönüşüm alanları mevcuttur. Gecekondu alanlarının 'iyileştirilmesi amacıyla', son yıllarda kentsel dönüşüm projeleri önerilmektedir. 1/25.000 ölçekli İzmir Büyükşehir Nazım İmar Planı (2009), afet yönetimi, risk alanlarının belirlenmesi ve kentsel sorunlara yönelik tedbirler gibi bütüncül politikalar içerir. Bu planda, İzmir'in konut birimlerinin \%39'unun sağlıksız, güvensiz, teknik standartlar açısından yetersiz olduğu tespit edilmiştir (Çelikbilek ve Öztürk, 2017, s. 198). Afet riskinin azaltılması ve önlenmesine yönelik uygulamalar içeren kentsel yenileme programı ilan edilmiştir. Daha sonra, 2012'de yürürlüğe giren 6306 sayılı Afet Riski Altındaki Alanların Dönüştürülmesi Kanununa göre, 33 mahallede, toplam 918,16 hektarlık, afet riskli altı alan belirlenmiştir (Çelikbilek ve Öztürk, 2017, s. 200).

Riskli alan ilan edilen gecekondu alanları lüks konut alanları arasına sıkışmış olan ve rant boşluğu oluşturan alanlardır. Bu alanlar, "değişim değeri" yaratacak dönüşüm projeleriyle, yoksulun "kullanım değeri" olan gecekonduları sermaye birikimine dahil edilebilecektir. Sermayenin kentsel alana çapa atmasıyla, konut ve arazi piyasasının ekonomideki ağırlığı ve piyasa aktörlerine bırakılan kâr payları, yoksulların konut piyasasından dışlanması ile sonuçlanabilmektedir. 


\section{İkinci İnönü Mahallesi ve Kentsel Dönüşüm Projesi}

İzmir'deki yoksulların konut sorununu, kentsel dönüşüm sonucu onları bekleyen mülksüzleşme ve dışlanmayı anlamak için İkinci İnönü Mahallesi'ndeki gecekondu alanı temsil edici bir örnektir. Narlıdere ilçesindeki eşitsiz gelişim, alanda çok belirgindir. Şekil 1'de görüldüğü gibi alanda, toplu konutlar, lüks konutlar, apartmanlar ve gecekondular bulunur. Güneyde, 1995'deki imar planına göre yapılan dönüşüm projesi ile inşa edilmiş toplu konut alanı (Narkent-Narbel) ve lüks konutlar bulunmaktadır. Alanın kuzeyinde, apartmanlar, lüks kapalı siteler; ilçenin sahil şeridinde ise, müstakil lüks konutlar bulunur.

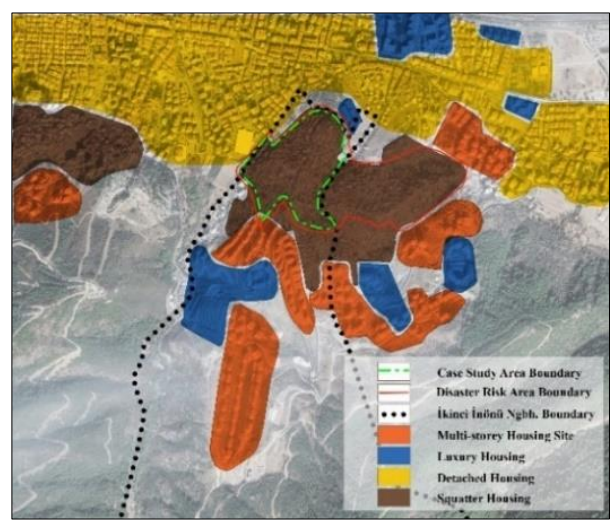

Şekil 1. Afet riskli ilan edilen gecekondu bölgesi ve çevresindeki konut tipleri (Kaynak:

Alan çalışması verilerine dayanarak hazırlanmıştır.)

İkinci İnönü Mahallesi 1981 yılında Bayındırlık ve İskan Bakanlığı tarafından onaylanan 1/5000 ve 1/1000 ölçekli imar planları ile planlanmıştır (Arkon, vd., 2010). 1/5000 ölçekli imar planına göre yerleşim alanı; orta yoğunluklu nüfus alanı, yeşil alan, sağlık tesisleri ve altyapısı ile birlikte planlanmıştır. Bu plana göre, çalışma alanı gecekondu önleme bölgesi olarak ilan edilmiştir (Şekil 2). 


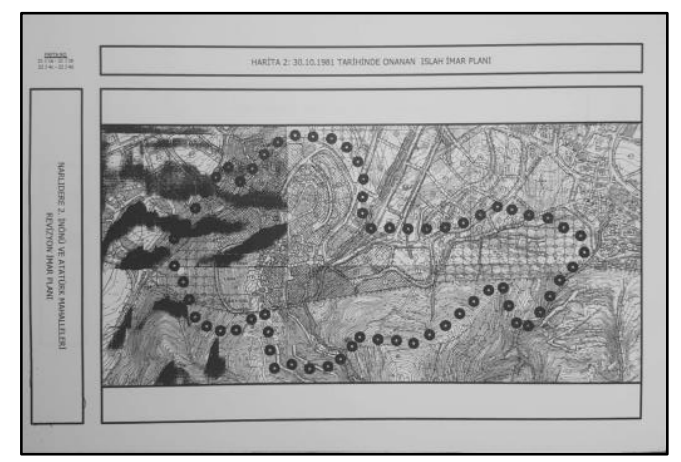

Şekil 2. 1/1000 ölçekli imar planı, 1981 (Kaynak: Revize İmar Planı Raporu, 2007)

Çalışma alanı 1989 yılında jeolojik etüt raporuna göre revize edilecek alan olarak belirlenmiştir (Şekil 3). Karar, İzmir Büyükş̧ehir Belediyesi tarafından onaylanmıştır (Arkon, vd., 2010).

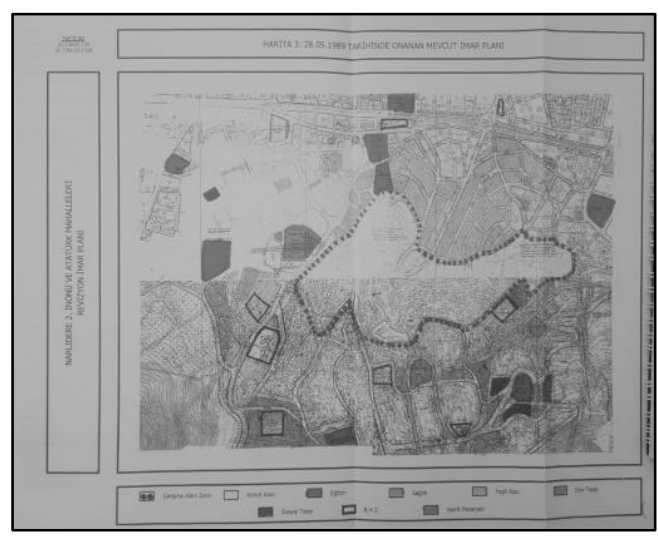

Şekil 3. 1/5000 ölçekli imar planı, 1989 (Kaynak: Revize İmar Planı Raporu, 2007)

1991 yılında revize edilen 1/5000 ölçekli plan 1994 senesinde İzmir Büyükşehir Belediyesi tarafından onaylanmıştır (Şekil 4). Bu plana göre konut yerleşimi orta yoğunluklu bir alan olacaktır; maksimum 200 kişi/ha olarak planlanmıştır. Yapılaşma koşulu ise, E=0,50-1,00 olarak belirlenmiştir. Çalışma alanı "gecekondu önleme alanı" statüsünü sürdürmektedir (Arkon, vd., 2010).

1994 yılına ait olan 1/5000 ölçekli plana göre, Atatürk ve İkinci İnönü Mahallelerini kapsayan gecekondu alanı jeolojik etüdü yapıldıktan sonra planı revize edilecek alan olarak belirlenmiştir. 


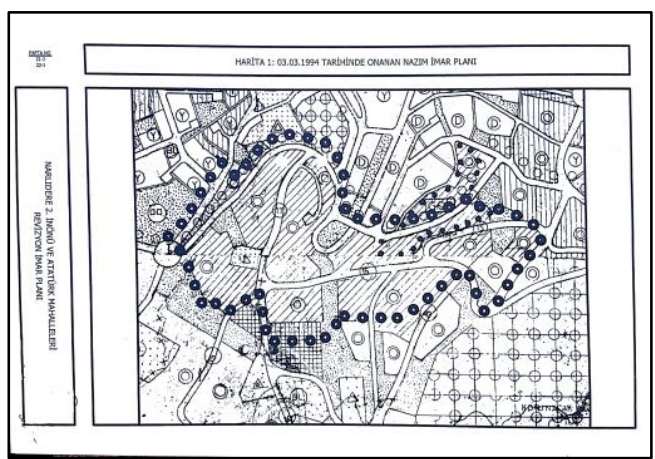

Şekil 4. 1/5000 ölçekli imar planı, 1994 (Kaynak: Revize İmar Planı Raporu, 2007)

Bu alan için 1995 ve 1997 yıllarında iki adet jeolojik etüt raporu oluşturulmuştur. 2000 yılına gelindiğinde jeolojik raporların yenilenmesi gerektiği ve alanın yüksek katlı yapılaşmaya uygun olmadığı kararı verilmiştir. Bu karara dayalı yeni revize imar planı 2002 senesinde hazırlanmıştır. Bu plana göre, Atatürk ve İkinci İnönü Mahallelerindeki yaklaşık 30 hektarlık gecekondu alanı jeolojik etüt raporu hazırladıktan sonra revize edilecek alan olarak belirlenmiştir. 2005 yılında hazırlanan jeolojik etüt raporu, 7269 sayılı kanun uyarınca Bayındırlık ve İskan Bakanlığı tarafından onaylanmıştır (Arkon, vd., 2010).

2007 senesinde Narlıdere Belediyesi bu alan için 1/1000 ölçekli imar planını hazırlamıştır (Şekil 5). Plan, 5216 sayılı Büyükşehir Belediyesi Kanunu gereği İzmir Büyükşehir Belediyesi'nin onayına sunulmuştur. İzmir Büyükşehir Belediyesi planın üst plan kararlarına uygunluğu, kütle yerleşimi, arazi sahipliği ve sosyal altyapı konuları bağlamında revize edilmesini talep etmiştir (Arkon, vd., 2010).

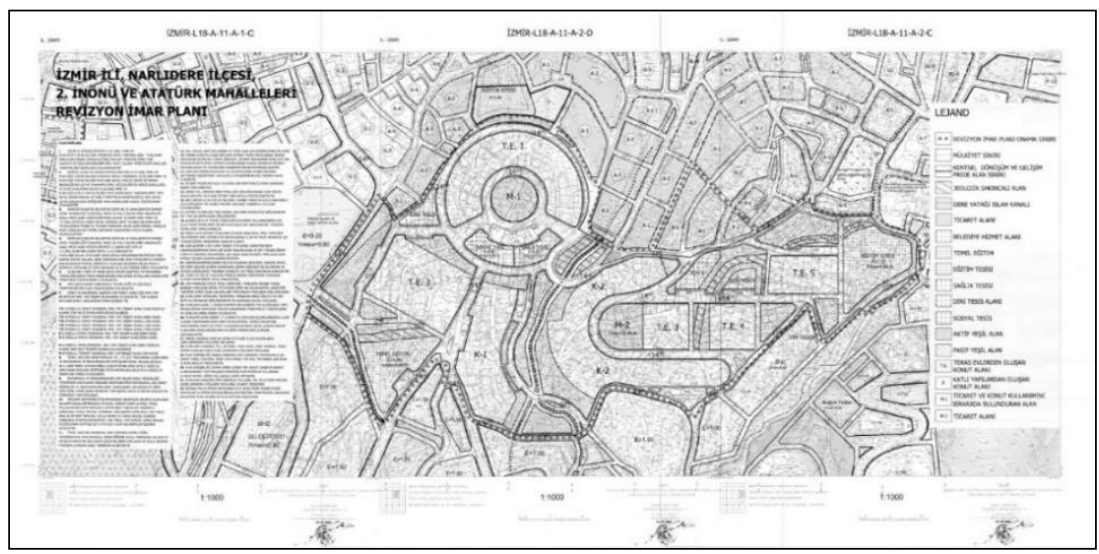

Şekil 5. 1/1000 ölçekli imar planı, 2007 (Kaynak: İzmir Şehir Plancıları Odası arşivi) 
2008 yılında 1/25000 ölçekli Nazım imar planında alan, dönüşüm alanı olarak ilan edilmiştir (Şekil 6). Narlıdere Belediyesi 1/1000 ölçekli planın İzmir Büyükşehir Belediyesinin revize istemi ve 1/25000 ölçekli plana göre yeniden hazırlanacağını beyan etmiştir (Arkon, vd., 2010).

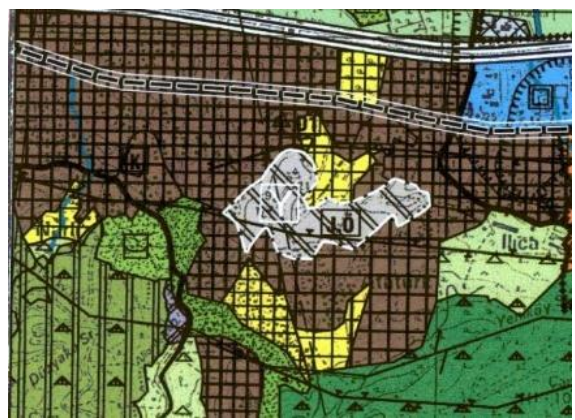

Şekil 6. 1/25000 ölçekli nazım imar planı, 2008

(Kaynak: İzmir Büyükşehir Belediyesi arşivi)

İmar planı sürecinin yanı sıra, alandaki mülkiyet sorunlarını çözmek amacı ile alan, 5393 sayılı Belediye Kanunu'nun 73. maddesine göre kentsel dönüşüm alanı olarak ilan edilmiştir.

2009 yılında, 2007 tarihli 1/1000 ölçekli imar planı yapılaşma koşullarındaki revizeler ile kabul edilmiştir. Yapılaşma kararları şu şekildedir: T.E. 1 (konut alanı) maksimum inşaat alanı $21.600 \mathrm{~m}^{2}$ (Birinci katta $2.700 \mathrm{~m}^{2}$ ticari alan olabilir.), T.E. 2 (konut alanı) maksimum inşaat alanı $18.000 \mathrm{~m}^{2}$, T.E. 3 (konut alanı) maksimum inşaat alanı $10.200 \mathrm{~m}^{2}$, T.E. 4 (konut alanı) maksimum inşaat alanı $10.200 \mathrm{~m}^{2}$, T.E. 5 (konut alanı) maksimum inşaat alanı $15.800 \mathrm{~m}^{2}, \mathrm{~K}$ 1 (konut alanı) maksimum inşaat alanı $26.000 \mathrm{~m}^{2}, \mathrm{~K}-2$ (konut alanı) maksimum inşaat alanı $51.400 \mathrm{~m}^{2}, \mathrm{M}-1$ (gelişme alanı) $13.500 \mathrm{~m}^{2}\left(4.500 \mathrm{~m}^{2}\right.$ ticari alan olarak kullanılabilir), M-2 (ticaret alanı) maksimum inşaat alanı $4.200 \mathrm{~m}^{2}$. Ek olarak, 2007 senesinde maksimum yükseklik serbest iken; revize planda konut alanları için $H_{\text {maks }}=24,80 \mathrm{~m}$ olarak belirlenmiştir (Arkon, vd., 2010).

2010 senesinde hazırlanan bilirkişi raporunda imar planı, planın üst ölçekler ile uyumu, planın jeolojik etüt raporu ile uyumu, imar planının arazi kullanım kararları ve yapılaşma koşullarının mevcut dokuya uyumu başlıkları altında değerlendirilmiştir. Rapora göre plan, jeolojik etüt raporu ile belgelenen alandaki eğime rağmen 8 katlı yapılaşma önerilmesi, 1/5000 ölçekli planda önerilen gecekondu önleme alanının bulunmaması yönleri ile İmar mevzuatına aykırı bulunmuştur (Arkon, vd., 2010). 
Alan son olarak, 6306 sayılı Afet Riski Altındaki Alanların Dönüştürülmesi Hakkında Kanuna göre, 15 Haziran 2013 tarihinde resmi gazetede yayınlanan Bakanlar Kurulu Kararı ile "riskli alan" ilan edilmiştir. İlan edilen riskli alan İkinci İnönü, Atatürk, Narlı ve Çatalkaya Mahallelerini kapsamaktadır. Çalışmanın alan araştırması ise, İkinci İnönü Mahallesine odaklanmaktadır; İkinci İnönü Mahallesi sınırlarında 14,74 hektar alan ve 622 gecekonduyu kapsamaktadır. Narlıdere Belediyesi, Çevre ve Şehircilik Bakanlığı tarafından kentsel dönüşüm için yetki sahibi kılınmıştır. Alan araştırması tamamlandıktan sonra, edinilen bilgiye göre Narlıdere Belediye başkanı Ali Engin, Çevre ve Şehircilik Bakanlığı Bakan yardımcısı Fatma Varank ile 2020 senesinin Temmuz ayında bir araya gelerek projeyi sunmuştur. Yenileme ve imar planı çalışmaları Bakanlık ve Belediye'nin birlikte çalışması ile yürütülmektedir (Emlak Kulisi, 2020; Evrensel Gazetesi, 2021).

\section{Gecekonduların Yapısal Özellikleri}

Gecekondu alanına ve konutlara dair veriler Narlıdere Belediyesi' nin kentsel dönüşüm projesi için hazırladığı analiz belgelerine dayanmaktadır. Belirtilmelidir ki, parseller ve gecekonduların mülkiyetleri ile ilgili veriler, 2018 y1lında yasalaşan ve İmar Barışı olarak tanımlanan yasa uyarınca söz konusu olabilecek değişiklikleri içermemektedir. Günümüzde daha fazla sayıda hanehalkı konutlarının mülkiyetine sahip durumda olabilir. Dönüşüm projesi kapsamindaki 622 gecekondunun \%0,64'ü yasal, \%35,20'si 1984 imar affı ile yasallaştırılmış, \%0,32'si yıkık binalardır. \%63,8'i ise gecekondu statüsündedir. Kaçak yapıların içinde kamusal binalar da (1 cami, 3 okul binası, 1 sağlık ocağı, 1 muhtarlık binası) bulunmaktadır. Yapıların \%93,56'sı konut, \%4,98'i ticaret, \%\%1,125'i ise kamu binasıdır. Parsellerin \%36,90'1 özel mülk, $\% 16,96$ 'sı hazine arazisi ve \%11,53'i Narlıdere Belediyesi'ne ait arazidir. Yanı sıra, \%3,05'i Narlıdere Belediyesi ve özel mülkiyet ortaklığı, \%0,24'ü İzmir Büyükşehir Belediyesi'ne ait arazi, \%0,06'sı İzmir Büyükşehir Belediyesi ve özel mülkiyet ortaklığı, \%0,107'si İzmir Büyükşehir Belediyesi, Narlıdere Belediyesi ve özel mülkiyet ortaklığıdır. \%31,13'ü ise cadde ve sokaklardır. Yap1 kalitesi analizine göre, alandaki binaların \%31,02'si kötü, \%55,2'si orta, \%13,02'si ise iyi kalitededir (Narlıdere Belediyesi arşivi). "Orta kalite"de, yap1 strüktürü, çatı, pencere ve kapıları sağlam, ancak yapı eskidir. Yıkılmış, farklı malzemeler ile tamir edilmeye çalışılmış ya da yıkık bırakılmış bölümleri olan yapılar, "kötü kalite" olarak tanımlanmıştır. 
Alan çalışması kapsamında elde edilen fiziksel veriler ise şu şekildedir: Ortalama konut alanı ve parsel büyüklüğü sırasılyla, $90 \mathrm{~m}^{2}$ ve $115 \mathrm{~m}^{2 \prime}$ dir. Konut birimlerinde ortalama oda sayısı 2 'dir. Kötü durumda ve altyapısı yetersiz de olsa, mutfak, tuvalet, banyo gibi temel imkanlar bulunmaktadır. Her birim teknik altyapıya sahiptir. Gecekonduların $\% 58,33$ 'ü bahçelidir.

\section{Gecekondu Sakinlerinin Sosyal ve Ekonomik Özellikleri}

Gecekondu alanının nüfusu 2.839 kişidir. Maksimum hane büyüklüğü 8; minimum 1; ortalama hane büyüklüğü ise 3,6'dır. Düzenli gelire sahip çalışan oranı \%14, inşaat işçiliği gibi düzensiz işlerde yevmiye ile çalışan oranı $\% 26^{\prime}$ dır. Alanda kendi işine sahip olanların oranı \%3,8 iken, \%46,8'i emeklidir. İşsizlik oranı, \%11,6'dır. Hanehalklarının \%75'inde çalışan kişi sayısı birden fazladır. Gecekondu alanında yaşayanların \%73,33'ü sosyal güvenceye sahiptir. Düzensiz istihdamla ilişkili olarak, sigortasız çalışan oranı \%20'dir. Hanelerin \%6,66'sı ise, devlet yardımı almaktadır.

Hanehalklarının \%8,33'ü 0-1.000TL, \%63,33'ü 1.001-2.000TL, \%23,33'ü 2.001-5.000TL arasında aylık gelire sahiptir. \%5'inin aylık geliri, 5.000TL'nin üzerindedir. Aylık geliri 2.000TL üzerinde olan hanelerin çoğu geleneksel geniş ailelerdir ve çalışan sayısı birden fazladır. 5.000TL üzerinde gelire sahip olan haneler ise konut kirası veya küçük ticaret gibi ek gelire sahiptir. Çalışmanın yürütüldüğü 2019 yılı Mart ayında, dört kişilik bir ailenin açlık limiti 2.014TL, yoksulluk limiti ise 6.561TL'dir (Türk-İş Raporu, son erişim tarihi: 17/04/2019). Buna göre, hanehalklarının yaklaşık \%72' sinin geliri açlık sınırı; neredeyse tamaminun geliri de yoksulluk sınırının altındadır.

İkinci İnönü Mahallesi'ni tercih etmelerinin temel nedenleri, göçtükleri dönemde mahallenin iş imkanlarına yakınlığı, konut yapabilecekleri uygun fiyatlı ve/veya boş arazilerin varlığı ve mahallede yaşayan akrabalarının olmasıdır.

Gecekondu sakinlerinin \%76,66'sı yaşadıkları konutun sahibidir. Konutlarını, İkinci İnönü Mahallesi'ne göç ettiklerinde inşa etmişlerdir. Akraba veya ailesinin evinde kira vermeden yaşayanların oranı, \%13,33'tür. Geniş aileler, bu gruba dahil edilmiştir. Kiracıların oranı \%10'dur. Kiracılar, kiraların düşük olması ve başka herhangi bir bölgedeki kirayı karşılayamadıkları için burayı tercih etmişlerdir.

Gecekondu alanında yaşayanların tamamı kentsel dönüşüm projesiyle konut sahibi olma beklentisi içindedir. Projeyi görenler, lüks konut projesi olduğunu ve aylık ödemelerde zorlanacaklarını, ödemeyi yapabilseler bile bu konutların aidatını ödeyemeyeceklerini belirtmişlerdir. Diğer yandan kiracı- 
lar ise, dönüşümden sonra Narlıdere'de barınamayacaklarını ve başka bir ilçeye taşınmak zorunda kalacakların ifade etmiştir. Gecekondu sakinlerinin $\% 43,33$ 'ü, ev sahibi olmak için aylık ödemeleri yapmaya çalışacaklarını; yaklaşık \%50'si aylık ödemeler nedeniyle memleketlerine, Narlıdere'nin başka mahallesine ya da başka ilçeye taşınmayı düşüneceklerini; \%6,66'sı ise mevcut konutlarını satıp, taşınacaklarını belirtmiştir.

\section{Kentsel Dönüşüm Projesi}

Belirtilmelidir ki, dönüşüm projesi hakkındaki bilgilerimiz, veri paylaşımındaki kısıtlamalar nedeniyle Narlıdere Belediyesi yetkilileri ile yüz yüze görüşmelere ve Narlıdere Belediyesi tarafından sağlanan bir kısım belgelere (görsellere) dayanmaktadır. Daha çarpıcı bir durum ise, alanda uzun yıllardır süregelen kentsel dönüşüm tartışmalarının yaşayanlar tarafından bilinmemesidir. 6306 sayılı kanun kapsamında hazırlanan imar planı ve proje çalışması Narlıdere Belediyesi tarafından Çevre ve Şehircilik Bakanlığı'nın onayına sunulduğu halde, gecekondu sakinleri uygulanacak kentsel dönüşüm projesi hakkında bilgilendirilmemişlerdir. Gecekondu halkı, projenin finansal yapısı, projeden doğan hakları veya kayıpları hakkında bilgi sahibi değildir (Evrensel Gazetesi, 2020, 2021). Projenin mali ve onay işlemlerinin tamamlanmadığı, bakanlık ve belediye arasında müzakerelerin devam ettiği bildirilmiştir.

Görüşmelerde elde edilen bilgiye göre, Narlıdere Belediyesi projenin yürütme mekanizması olarak, Belediye ve özel bir firma arasında \%50'ye dayanan bir ortaklık kuracaktır. Ayrıca, gecekonduda yaşayan kiracılar dahil herkesin hak sahibi sayılacağı belirtilmiştir. Narlıdere Belediyesi'ne göre proje \%100 uzlaşma ile yürütülecektir ve katılımcı bir süreç izlenecektir. Halen, dönüşüme esas olacak imar planı henüz onaylanmamış, imar planı uyarınca bir uygulama projesi uyarınca hak sahipleri ile uzlaşma görüşmeleri yapılmamıştır. Bu nedenlerle gecekondu sakinlerinin tapu senedi hakkının çerçevesini belirleyen bir sözleşme yapılmamış ve geri ödeme planı tanımlanmamıştır. İmar planı ve dönüşüm projesi Çevre ve Şehircilik Bakanlığı tarafından onaylandıktan sonra, gecekondu sakinleriyle uzlaşma süreci başlatılacak ve hazırlanacak dönüşüm projesi uyarınca haklarını tanımlayan sözleşme imzalanacaktır. Ek olarak, Narlıdere Belediyesi yetkilileri, projenin hedef kitlesini orta ve yüksek gelir grubu olarak tanımlamıştır (Narlıdere Belediyesi'nde yüz yüze görüşme, 26.11.2018). 


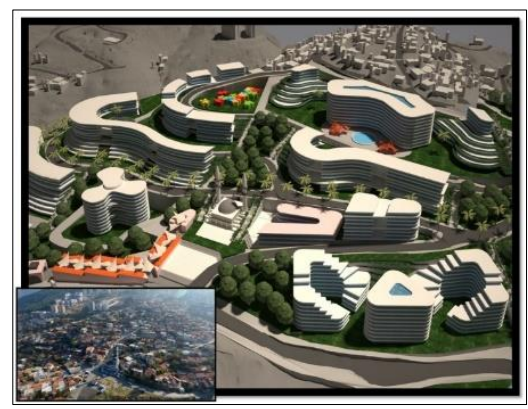

(a)

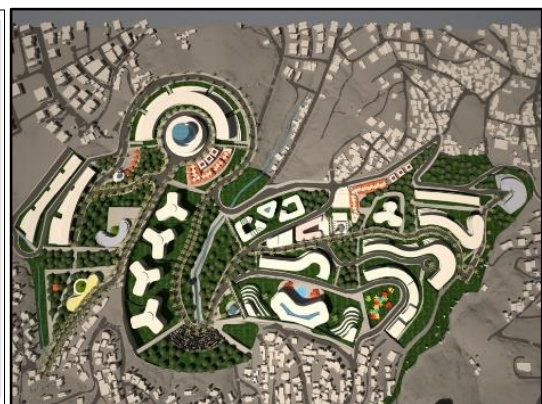

(b)

Şekil 7. (a) İkinci İnönü ve Atatürk Mahallelerinin gecekondu alanlarını kapsayan kentsel dönüşüm projesinin üç boyutlu görüntüsü, (b) İkinci İnönü ve Atatürk Mahallelerinin gecekondu alanlarını kapsayan kentsel dönüşüm projesinin tepeden görünüşü (Kaynak:

Narlıdere Belediyesi, 2019)

Şekil 7 gecekondu alanı için hazırlanan projenin görselidir. Proje, konut birimleri, ticari alan, sosyal altyapı ve yeşil alanlar içeren bir kompleks olarak tasarlanmıştır. Anlaşıldığı üzere kütleler, Şekil 5'te görülen ve 2009 senesinde revize edilerek onaylanan imar planının yapılaşma koşullarına benzerdir. Nitekim Çevre ve Şehircilik Bakanlığı'nda devam etmekte olan imar planı ve proje onay prosedürlerinden kaynaklandığı belirtilen kısıtlamalar nedeniyle görüşmeler sırasında alan büyüklüğü ve arazi dağılımı, birim sayısı ile ilgili veriler paylaşılmamıştır. Görselden anlaşılacağı gibi, yapılar gecekonduların toplumsal-mekansal ve doğal özelliklerine uzak, çok katlı, büyük bloklardan oluşmaktadır.

Belediyede yapılan görüşmeler ve alan gezileri sırasında yapılan görüşmelerde, gecekondu halkının kentsel dönüşüm yapılacağından haberdar, ancak projedeki hakları veya kayıpları hakkında bilgi sahibi olmadığı tespit edilmiştir. Büyük çoğunluğunun, İkinci İnönü Mahallesi Muhtarlığında örneği bulunan kentsel dönüşüm projesi görselinden de habersiz olduğu gözlenmiştir. Ek olarak, alan görüşmeleri sırasında gecekonduda yaşayanlar, deniz gören konutta oturmaları, bahçe sahibi olmaları ve kendi inşa ettikleri çok katlı konutta birden fazla hane olarak yaşamalarını gerekçe göstererek, kentsel dönüşüm projesinden paylarına düşecek olana itiraz edeceklerini belirtmişlerdir.

Diğer yandan, apartman dairesi formu gecekondu sakinlerinin ortalama aile büyüklüğüne, yaşam tarzına uygun değildir. Alanda yaşayanlar projeyi bir ev sahibi olmak, daha sağlıklı bir yaşam sürmek, çocuklarına güvenli bir gelecek beklentisiyle desteklemektedir. Ancak, ekonomik olarak karşılayabilecekleri bir toplu konut projesine de razı olacaklarını vurgulamışlardır. 


\section{Konuta Ekonomik Erişilebilirlik (Housing Affordability Index - HAI)}

Konutun satın alınabilirliği, konutun metalaştırılması ile doğrudan bağlantılıdır. Konutu bir ihtiyaç olarak tanımlayan kullanım değeri yerine, ekonomik değişim değerini vurgulamaktadır. Sonraki sayfalarda, konuta ekonomik erişilebilirlik endeksi (HAI) hesaplamalarının da gösterdiği gibi, Narlıdere'de 1990'lardan bu yana üretilen konutların artan değişim değeri, gecekonduların kullanım değeri üzerinde baskı oluşturmaktadır.

Konuta ekonomik erişilebilirlik, konut için harcanan gelir oranıdır. Diğer bir değişle, diğer mal ve hizmetlere karşı, konutun gölge maliyetidir (Hancock, 1993; Linneman ve Megbolugbe, 1992; Stone, 2006). İki farklı yaklaşımla ölçülür. Birincisi, konut maliyetleri ve hanehalkı geliri arasındaki ilişkiyi değerlendiren oransal yaklaşımdır. Hanehalkının konut giderine yaptığı harcamaların, gelirlerine bağlı sınırlı seçenekleri arasından bir tercih olduğunu varsayar. Eğer hanehalkı gelirinin belirli bir oranından fazlasını konuta harcamak zorundaysa, geliri diğer temel ihtiyaçlarına yetmeyecektir. Ülkelerin demografik ve ekonomik özelliklerine bağlı olarak konut maliyetinin gelire göre ekonomik oran eşikleri \%25, \%30, \%40 ve \%50 kabul edilir (Kutty, 2005; Padley ve Marshall, 2019). Oranlar, teorik olarak kanıtlanmış değildir, ortak varsayıma dayanır (Stone, 2006). Genel kabule göre, hanehalkı, gelirinin \%30'undan fazlasını konuta ayırmak zorunda ise, konut ihtiyacını karşılayamaz (Baker, vd., 2015). İkinci yaklaşım da bir temel varsayıma dayanır: Gelir ve konut arasındaki ilişkinin göstergesi, konut giderinin gelire oranı değil, konut harcamasına ayrılacak hipotetik bütçeden geriye kalan gelirdir. Hanehalkı, konut dışı harcamalarını, konut maliyetleri yüzünden kısıtlamak zorundaysa, barınma yoksuludur (Padley ve Marshall, 2019; Stone, 2006).

Türkiye'de konuta erişilebilirlik, konut giderleri, beslenme, sağlık, eğitim, giyim, çocuk bakımı gibi diğer temel ihtiyaçların kısıtlanmasına neden olduğu için ciddi bir sorundur. Zaten, İkinci İnönü Mahallesinde tasarlanan kentsel dönüşüm projesinin hedefinde olan gecekondu sakinlerinin hemen tamamı yoksulluk sınırı altında ve düzensiz gelirle yaşamak zorundadır. Farklı oranlarda konut harcaması varsayılarak oluşturulan iki farklı senaryo ile gecekonduda yaşayanların proje sonrasındaki olası durumları incelenmiştir. Kurgulanan metriğin temel parametreleri, hanehalkı ortalama gelir durumu, çalışmanın yapıldığı döneme ait faiz oranları (2019), Narlıdere'de ortalama konut metrekare fiyatları (2019) ve ortalama birim büyüklügüdür. Ortalama büyüklük, İzmir'de benzer sosyal, ekonomik ve mekansal özelliklere sa- 
hip alanlarda uygulanmış kentsel dönüşüm projelerindeki değerlere göre belirlenmiştir. Her iki senaryoda konut alanı, $80 \mathrm{~m}^{2}$ 'dir. Endeks hesaplama sonuçları, hanehalklarının kredi geri ödeme kapasitelerine göre yorumlanmaktadır.

Burada belirtilmelidir ki, çalışma kapsamında kullanılan HAI hesaplama yöntemi, varsayımlara dayanmaktadır. Zira, halen hem Bakanlık onayına sunulan ancak üretilecek mekânsal birimler ve kullanımlara, finansal yapısına, hem de olası hak sahipliği ve kamulaştırma ve enkaz değerlemelerine dair veri elde edilememiştir. Diğer yandan, alandan elde edilen hanehalkı geliri verisine dayanarak ve farklı borçlanma oranları da varsayılarak, sadece projenin uygulanması sonucu gecekonduluları bekleyen olası sonuçları gösterebilecek bir hesaplama tekniği olarak kabul edilmiştir. Araştırma kapsamında uygulanan yöntemin Türkiye ve gecekondu alanlarına dair daha ayrıntılı veri ile desteklenmesi, uygunluğunun daha ayrıntılı bir şekilde incelenmesi ve yerel koşullara daha uygun bir yöntem geliştirilmesi gereklidir.

Çalışma, imar affi ile yasallaştırılmış gecekondular ve özel mülkiyetteki arsalar üzerindeki yapıları kapsamaktadır. Benzer projelere dayanarak, gecekondu statüsündeki yapıların enkaz ve/veya kamulaştırma bedelleri üzerinden uzlaşmaya gidileceği düşünülmektedir. Bu noktada belirtilmelidir ki, Narlıdere Belediyesi, alandaki kiracılar dahil tüm yaşayanların proje kapsamında hak sahibi sayılacağını ve sürecin uzlaşma ile yürütüleceğini beyan etmiştir.

Kurgulanan ilk senaryo, kredi geri ödeme peşinatınn ödemelerdeki payına dayanmaktadır. Narlıdere Belediyesi'nin kredilerin geri ödemeleri hesaplanmasında arsa maliyetini, konut fiyatından peşinat olarak çıkarmayı planladığı öğrenilmiştir. Çeşitli olasılıkları karşılaştırabilmek için bu oran, \%20, \%30, \%40, \%50 olarak varsayılmış, dört seçenek hazırlanmıştır. Kredi ödemelerinin hanehalkı gelirindeki payının $\% 25$ olacağı varsayılmıştır.

İkinci senaryoda ise, kredi ödeme paylarının hanehalkı geliri içinde \%20, \%30, \%40, \%50 oranında değişeceği varsayılmıştır. İkinci senaryoyu kurgulamamızın nedeni, gecekondu sakinlerinin toplumsal ve kültürel özellikleri, yeni ve yaşanabilir, "tapulu" bir ev sahibi olma istekleri ve bunun için hanehalkı bütçesini olabildiğince zorlayacaklarına dair gözlemlerimizdir.

İkinci İnönü Mahallesi'ndeki ortalama konut fiyatı Mart 2019 tarihinde çevrimiçi veri kaynaklarından alınan verilere göre, $4.726 \mathrm{TL} / \mathrm{m} 2$ olarak hesaplanmıştır (Sahibinden Emlak, son erişim tarihi: 17.03.2019). 2019 yılı Mart ayında konut fiyatları için, en uygun faiz oranını sunan Ziraat Bankası'nın çevrimiçi kredi planı hesaplayıcısı ile geri ödeme planları hesaplanmıştır. Konut kredisi faiz oranı \%1,45'tir (Ziraat Bankası, 2019). Kredi geri ödeme planının 120 ay vadeli olduğu varsayılmıştır. 
Yeterlik geliri, temel ihtiyaçlar için yapılan harcamalar ve diğer birincil giderler için ayrılan para aylık gelirden çıkarıldıktan sonra, konut kredisini kolay bir şekilde ödemek için kalan gelir olarak tanımlanmaktadır. Çalışma kapsamında ise, konut gideri için hanehalkı gelirinin \%25'inin ayrılacağı varsayımına dayanarak, yeterlik geliri konut kredisi aylık geri ödeme miktarının dört katı şeklinde kabul edilmiştir. Saha çalışması sırasında belirlenmiş olan gelir aralıkları ortalama değerlerinde sabitlenerek (500TL, 1.500TL, 3.500TL, 7.500TL) hesaplama yapılmıştır.

Konuta ekonomik erişilebilirliği hesaplamak için, "HAI= Ortalama hanehalkı geliri/ Yeterlilik geliri¹00" denklemi kullanılmaktadır. Yani, ortalama hanehalkı geliri, ortalama bir konutu almaya yeterli olduğunda HAI değeri 100'dür. Endeks değerinin daha yüksek çıması, hanehalkının daha iyi bir ev satın alabileceğini göstermektedir.

\section{Senaryo 1}

Bu model, arsa bedelinin kredi geri ödemelerinde $\% 20, \% 30, \% 40$ ve $\% 50$ oranlarında peşinat olarak sayılmasına dayanmaktadır. Hanehalkının ödemeleri kolaylıkla yapabilmesi için sahip olması gereken aylık gelir de, aylık geri ödeme hanehalkı gelirinin \%25'i olacak şekilde hesaplanmıştır.

Tablo 1. Senaryo 1 için konut satış fiyatı, farklı oranlar için konut kredisi geri ödeme miktarı, aylık yeterlilik geliri bilgileri

\begin{tabular}{|c|c|c|}
\hline Konut bilgileri & $\begin{array}{l}\text { Konut birimi }\left(\mathrm{m}^{2}\right) \mathrm{m}^{2} \text { fiyatı } \\
\text { Konutun satış fiyatı }\end{array}$ & $\begin{array}{l}80 \mathrm{~m}^{2} \\
4.726 \mathrm{TL} \\
378.080 \mathrm{TL}\end{array}$ \\
\hline $\begin{array}{l}\text { Arsa bedelinin } \% 20 \text { peşinat } \\
\text { olarak sayılacağ senaryo } 1 \text {-a }\end{array}$ & $\begin{array}{l}\text { Ön ödeme olarak sayılacak arsa bedeli } \\
120 \text { ay vadeli konut kredisi miktarı } \\
\text { Konut kredisi aylık geri ödeme miktarı } \\
\text { Aylık yeterlilik geliri }\end{array}$ & $\begin{array}{l}75.616 \mathrm{TL} \\
302.464 \mathrm{TL} \\
5.333 \mathrm{TL} \\
21.332 \mathrm{TL} \\
\end{array}$ \\
\hline $\begin{array}{l}\text { Arsa bedelinin } \% 30 \text { peşinat } \\
\text { olarak sayılacağı senaryo } 1-b\end{array}$ & $\begin{array}{l}\text { Ön ödeme olarak sayılacak arsa bedeli } \\
120 \text { ay vadeli konut kredisi miktarı } \\
\text { Konut kredisi aylık geri ödeme miktarı } \\
\text { Aylık yeterlilik geliri }\end{array}$ & $\begin{array}{l}113.424 \mathrm{TL} \\
264.656 \mathrm{TL} \\
4.666 \mathrm{TL} \\
18.664 \mathrm{TL} \\
\end{array}$ \\
\hline $\begin{array}{l}\text { Arsa bedelinin } \% 40 \text { peşinat } \\
\text { olarak sayılacağı senaryo } 1-c\end{array}$ & $\begin{array}{l}\text { Ön ödeme olarak sayılacak arsa bedeli } \\
120 \text { ay vadeli konut kredisi miktarı } \\
\text { Konut kredisi aylık geri ödeme miktarı } \\
\text { Aylık yeterlilik geliri }\end{array}$ & $\begin{array}{l}151.232 \mathrm{TL} \\
226.848 \mathrm{TL} \\
4.000 \mathrm{TL} \\
16.000 \mathrm{TL}\end{array}$ \\
\hline $\begin{array}{l}\text { Arsa bedelinin } \% 50 \text { peşinat } \\
\text { olarak sayılacağ } \text { senaryo } 1-d\end{array}$ & $\begin{array}{l}\text { Ön ödeme olarak sayılacak arsa bedeli } \\
120 \text { ay vadeli konut kredisi miktarı } \\
\text { Konut kredisi aylık geri ödeme miktarı } \\
\text { Aylık yeterlilik geliri }\end{array}$ & $\begin{array}{l}\text { 189.040TL } \\
\text { 189.040TL } \\
\text { 3.333TL } \\
13.332 \mathrm{TL} \\
\end{array}$ \\
\hline
\end{tabular}


Tablo 1'de, bu oranlara karşılık gelen miktarlar ve hanehalkının kredi geri ödemelerini rahatlıkla yapabilmesi için sahip olması gereken aylık gelir miktarı gösterilmektedir.

\section{Senaryo 1-a}

Bu senaryoda, gecekondunun arsa bedelinin kentsel dönüşüm projesindeki konutlar için \%20 peşinatı karşılayacağı, kalan \%80'in ise kredi ödemesi şeklinde yapılacağı varsayılmıştır.

Tablo 2. Senaryo 1-a için konuta erişilebilirlik endeksi (HAI) değerleri

\begin{tabular}{lll}
\hline Ortalama hanehalkı geliri & HAI denklemi & HAI değeri \\
\hline $500 \mathrm{TL}$ & $\mathrm{HAI}=500 \mathrm{TL} / 21.332 \mathrm{TL}^{*} 100$ & 2,34 \\
\hline $1.500 \mathrm{TL}$ & $\mathrm{HAI}=1.500 \mathrm{TL} / 21.332 \mathrm{TL}^{*} 100$ & 7,03 \\
\hline $3.500 \mathrm{TL}$ & $\mathrm{HAI}=3.500 \mathrm{TL} / 21.332 \mathrm{TL}^{*} 100$ & 16,40 \\
\hline $7.500 \mathrm{TL}$ & $\mathrm{HAI}=7.500 \mathrm{TL} / 21.332 \mathrm{TL}^{*} 100$ & 35,15 \\
\hline
\end{tabular}

Tablo 1, hanehalkının kentsel dönüşüm projesinden konut sahibi olmak için aylık yeterlilik gelirinin 21.332TL olması gerektiğini; hanehalkları gelirlerinin konut sahibi olmak için yetersiz olduğunu göstermektedir. Tablo 2'de görüldüğü üzere ise, konuta erişilebilirlik endeksine göre, konut sahibi olmak için gereken oran aylık 100 iken, hanehalkları için sırasıyla \%2,34, \%7,03, $\% 16,40, \% 35,15$ oran hesaplanmıştır.

\section{Senaryo 1-b}

Gecekondunun arsa bedelinin kentsel dönüşüm projesindeki konutlar için \%30 oranında peşinatı karşılayacağı, kalan \%70'in ise kredi ile ödeneceği varsayılmıştır. Tablo1, bu senaryoya göre aylık yeterlilik gelirinin 18.664TL olması gerektiğini göstermektedir.

Tablo 3. Senaryo 1-b için konuta erişilebilirlik endeksi (HAI) değerleri

\begin{tabular}{lll}
\hline Ortalama hanehalkı geliri & HAI denklemi & HAI değeri \\
\hline $500 \mathrm{TL}$ & HAI $=500 \mathrm{TL} / 18.664 \mathrm{TL}^{*} 100$ & 2,67 \\
\hline $1.500 \mathrm{TL}$ & $\mathrm{HAI}=1.500 \mathrm{TL} / 18.664 \mathrm{TL} * 100$ & 8,03 \\
\hline $3.500 \mathrm{TL}$ & $\mathrm{HAI}=3.500 \mathrm{TL} / 18.664 \mathrm{TL} * 100$ & 18,75 \\
\hline $7.500 \mathrm{TL}$ & $\mathrm{HAI}=7.500 \mathrm{TL} / 18.664 \mathrm{TL} * 100$ & 40,18 \\
\hline
\end{tabular}

Tablo 3'te görüldüğü gibi, konuta erişilebilirlik endeksine göre, konuta kolaylıkla sahip olmaları için gereken oran 100 iken, hanehalkları için sırasiyla hesaplanan oran $\% 2,67, \% 8,03, \% 18,75, \% 40,18^{\prime}$ dir.

\section{Senaryo 1-c}

Bu senaryoya göre, gecekondunun arsa bedelinin kentsel dönüşüm projesindeki konutlar için \%40 peşinat olacağı ve kalan \%60'1n ise kredi ödemesi 
şeklinde yapılacağı varsayılmıştır. Tablo 1'e göre hanehalkının kredi geri ödemelerini rahatlıkla yapabilmesi için sahip olması gereken aylık gelir miktarı 16.000TL'dir.

Tablo 4. Senaryo 1-c için konuta erişilebilirlik endeksi (HAI) değerleri

\begin{tabular}{lll}
\hline Ortalama hanehalkı geliri & HAI denklemi & HAI değeri \\
\hline $500 \mathrm{TL}$ & HAI $=500 \mathrm{TL} / 16.000 \mathrm{TL}^{*} 100$ & 3,13 \\
\hline $1.500 \mathrm{TL}$ & HAI $=1.500 \mathrm{TL} / 16.000 \mathrm{TL}^{*} 100$ & 9,37 \\
\hline $3.500 \mathrm{TL}$ & HAI $=3.500 \mathrm{TL} / 16.000 \mathrm{TL}^{*} 100$ & 21,87 \\
\hline $7.500 \mathrm{TL}$ & HAI $=7.500 \mathrm{TL} / 16.000 \mathrm{TL} * 100$ & 46,87 \\
\hline
\end{tabular}

Tablo 4'te görüldüğüü üzere, gecekonduda yaşayanların kentsel dönüşüm projesinden konut sahibi olabilmeleri için sahip olmaları gereken oran 100 iken, hanehalklarının sahip olduğu oran sirasiyla \%3,13, \%9,37, \%21,87, $\% 46,87^{\prime}$ dir.

\section{Senaryo 1-d}

Bu senaryoda, gecekondunun arsa bedelinin, projedeki konutlar için $\% 50$ oranında peşinat sayılacağı, kalan \%50'nin ise kredi geri ödemesi şeklinde olacağı varsayılmıştır. Tablo 1'e göre, hanehalkının krediyi kolaylıkla ödeyebilmek için sahip olması gereken yeterlilik geliri 13.332TL olmalıdır.

Tablo 5. Senaryo 1-d için konuta erişilebilirlik endeksi (HAI) değerleri

\begin{tabular}{lll}
\hline Ortalama hanehalkı geliri & HAI denklemi & HAI değeri \\
\hline $500 \mathrm{TL}$ & HAI $=500 \mathrm{TL} / 13.332 \mathrm{TL}^{*} 100$ & 3,75 \\
\hline $1.500 \mathrm{TL}$ & HAI $=1.500 \mathrm{TL} / 13.332 \mathrm{TL}^{*} 100$ & 11,25 \\
\hline $3.500 \mathrm{TL}$ & HAI $=3.500 \mathrm{TL} / 13.332 \mathrm{TL}^{*} 100$ & 26,25 \\
\hline $7.500 \mathrm{TL}$ & HAI $=7.500 \mathrm{TL} / 13.332 \mathrm{TL}^{*} 100$ & 56,25 \\
\hline
\end{tabular}

Tablo 5'ten anlaşıldığı üzere, hanehalklarının ekonomik durumu gecekondu bedeli \%50 olarak sayılsa bile, konut sahibi olmak için yetersizdir. Konuta erişilebilirlik endeksine göre, konuta kolaylıkla sahip olmaları gereken oran 100 iken, hanehalkları için hesaplanan oran sırasıly $\% 3,75, \% 11,25$, $\% 26,25, \% 56,25$ 'dir.

\section{Senaryo 2}

Kurgulanan ikinci modelde, kredi geri ödemesinin hanehalkı geliri içindeki payı \%20, \%30, \%40, \%50 oranlarında değişmektedir. Arsa bedeli ise konut fiyatının \%25'i olarak sabit kabul edilmiştir. Tablo 6, konuta dair bilgileri, \%25 oranında olacağı kabul edilen arsa bedelini, kredi ödemesi şeklinde yapılacak olan miktarları özetlemektedir. 
Tablo 6. Senaryo 2 için konut satış fiyatı, konut kredisi geri ödeme miktarı bilgileri

\begin{tabular}{ll}
\hline Konut birimi $\left(\mathrm{m}^{2}\right)$ & $80 \mathrm{~m}^{2}$ \\
\hline $\mathrm{m}^{2}$ fiyatı & $4.726 \mathrm{TL}$ \\
\hline Konutun satış fiyatı & $378.080 \mathrm{TL}$ \\
\hline Ön ödeme olarak sayılacak arsa bedeli & $94.520 \mathrm{TL}$ \\
\hline 120 ay vadeli konut kredisi miktarı & $283.560 \mathrm{TL}$ \\
\hline Konut kredisi aylık geri ödeme miktarı & $5.000 \mathrm{TL}$ \\
\hline
\end{tabular}

Tablo 7. Farklı kredi geri ödeme paylarına göre hanehalklarının kredi ödeme miktarları

\begin{tabular}{lll}
\hline Ortalama hanehalkı geliri & Kredi geri ödeme payı & Hanehalkını ödeyeceği miktar (TL) \\
\hline \multirow{5}{*}{$500 \mathrm{TL}$} & $\% 20$ & $100 \mathrm{TL}$ \\
& $\% 30$ & $150 \mathrm{TL}$ \\
& $\% 40$ & $200 \mathrm{TL}$ \\
& $\% 50$ & $250 \mathrm{TL}$ \\
\hline \multirow{5}{*}{$1.500 \mathrm{TL}$} & $\% 20$ & $300 \mathrm{TL}$ \\
& $\% 30$ & $450 \mathrm{TL}$ \\
& $\% 40$ & $600 \mathrm{TL}$ \\
$3.500 \mathrm{TL}$ & $\% 50$ & $750 \mathrm{TL}$ \\
& $\% 20$ & $700 \mathrm{TL}$ \\
& $\% 30$ & $1.050 \mathrm{TL}$ \\
$7.500 \mathrm{TL}$ & $\% 40$ & $1.400 \mathrm{TL}$ \\
& $\% 50$ & $1.750 \mathrm{TL}$ \\
\hline
\end{tabular}

Bu senaryoya göre, aylık 5.000TL kredi geri ödemesi yapılması gerekmektedir. Tablo 7' de görüldügü üzere ise, hanehalkları aylık gelirlerinin yarısını kredi taksitleri için ayırsalar bile, en yüksek gelir grubu kredi geri ödemesi için ayırabileceği 3.750TL bütçeye sahiptir. Hesaplamalar göstermektedir ki, gecekondu sakinlerinin hiçbiri, konut sahibi olmak için yeterli ekonomik güce sahip değildir.

Öte yandan, en iyimser varsayımla, peşin ödeme için arazi maliyetinin ve geri ödeme taksitlerinin payı her biri için $\% 50$ olduğunda, ayrıca hanehalklarının aylık gelirlerinin \%50'sini geri ödemeler için ayırdığında bile, hanehalklarının sadece $\% 5^{\prime}$ i, 3.333TL aylık taksiti olan kredi ödemelerini yapabilir.

Sonuçta, İkinci İnönü Mahallesi gecekondu sakinlerinin kentsel dönüşüm ile konut sahibi olmak, barınma ihtiyaçlarını gidermek için diğer temel ihtiyaç harcamalarını azaltmaları gerekecektir ve ekonomik olarak konuta erişebilir durumda değildirler. 


\section{Tartışma ve Sonuç}

Neoliberal politikalar altında spekülatif konut üretimi, konutun değişim değerinin kullanım değerine hakim olmasıyla tanımlanır. 1980'lerle başlayan neoliberal makroekonomik dönüşümler ve devletin yeniden yapılanması ile, kentlerin sermaye birikim alanına dönüşmesi yan yanadır. Toplu konut ve kentsel dönüşüm projeleri, rant boşluğu yaratma ve kapatma ve sermaye birikiminin en önemli aracı haline geldikçe, yoksullar kendileri için kullanım değeri olan konutlarını kaybederek mülksüzleştirilmektedir. Kuyucu ve Ünsal (2010), Türkün (2015), Erman (2016), Topal, Yalman ve Çelik (2019), rant boşluğunun yaratılması ve kapanması ile ortaya çıkan rantın elde edilmesi ve dağıtımından, düşük gelirli ve yoksul gecekondu sakinlerinin tamamen dışlandığını, mülksüzleştiğini göstermiştir.

Narlıdere'de 1990'lardan beri giderek artan lüks konut gelişimi; planlı gelişen bu alanlarda artırılmış yoğunluk ve imar hakları, çok hızlı yükselen gayrimenkul fiyatları, giderek artan bir rant boşluğu yaratmaktadır. Narlıdere Belediyesi, dönüşüm projesinin katılımcı bir şekilde yürütüleceğini ve İkinci İnönü Mahallesi gecekondu alanındaki bütün hanelerin kentsel dönüşüm projesinde hak sahibi olarak kabul edileceğini ifade etmiştir. Proje, Narlıdere Belediyesi tarafından Çevre ve Şehircilik Bakanlığı'nın onayına sunulmuştur. Ancak, gecekondu sakinleri, projenin tasarım aşamasına dahil edilmemişler; hakları ve dönüşüm projesinden veya projenin finansal yapısından kaynaklanabilecek kayıpları konusunda bilgi sahibi değildirler.

Saha çalışması esnasında görüşülen bütün gecekonduluların beklentisi, dönüşüm projesinden sonra konut sahibi olmaktır. Ancak, olası konut maliyetlerini karşılamaları mümkün görünmemektedir. Çalışma kapsamında oluşturulan ekonomik erişilebilirlik senaryolarından sadece birinde, hanehalklarının \%5'i konut sahibi olabilecektir. Öyle ki, ancak sahip oldukları gecekondunun arsa bedeli \%50 peşinat olarak kabul edilir ve hanehalkı gelirinin \%50'si konut ödemelerine ayrilırsa, kentsel dönüşüm projesinden konut sahibi olabilecektir. Elbette bu, gecekondu sahipleri eğer binanın bulunduğu arsanın da sahibi ise mümkündür. Ayrıca, taksit ve aylık aidatları düzenli olarak ödeyebilecekleri de son derece iyimser bir varsayımdır. Alan çalışması esnasında yapılan görüşmelerde gecekonduda yaşayanlar, dönüşüm ile üretilen konutların taksit ve aidat ödemelerini düzenli yapabilmeleri için yeni bir iş bulmaları gerektiğini belirtmişlerdir. Bir yandan sadece süreksiz ve güvencesiz, düşük gelirli işler bulabilecekler, diğer yandan sürekli ve düzenli ödeme yükümlülügü altında olacaklardır. 
Kentsel dönüşüm projesinin henüz uygulama esasları netleşmediğinden, proje uygulanmaya başlamadığından ve projenin sonuçları gözlemlenemediğinden; çalışma kapsamında yapılan eleştiriler doğrudan hiçbir aktöre yönelik değildir. Eleştirilerimizin projenin hazırlanma ve yürütülme sürecindeki gizliliğe, sonuçlardan doğrudan etkilenecek olan gecekonduda yaşayan halkın proje hazırlanma aşamasına dahil edilmemesine, ilgili yasadaki açıklara ve projenin gecekondu alanının konumu itibariyle yüksek rant getireceği bilinerek bir rant aracı olarak tasarlanmasına olduğunu da belirtiriz.

İkinci İnönü Mahallesinde uygulanacak kentsel dönüşüm projesinin orta ve üst gelir gruplarını hedeflediği, projenin $\% 50^{\prime}$ lik belediye ve özel şirket ortaklığı ile yürütüleceği, Narlıdere'de sürekli artan konut ve arazi fiyatları, gecekondu halkının gelir düzeyi ve konuta erişebilirlik endeksi hesaplamaları göz önüne alındığında, proje, açıkça gecekonduların temizlenmesine yönelik bir mekânsal müdahale olacaktır. En iyimser varsayımlara dayanan konuta erişebilirlik hesaplamalarında da görüldüğü gibi, alanda yaşayanların çok büyük bir kısmını bekleyen, sosyal ve mekânsal dışlanma, mülksüzleştirilerek yerinden edilmedir.

Böylesi projelerin başka türlü sonuçlanması için, konut üretiminde öncelikle konut hakkı vurgusu ile konutun kullanım değeri, değişim değerine karşı savunulmalıdır. Yoksulların ihtiyaç ve taleplerine uygun konut üretimine öncelik tanınmall; konut üretiminde özel sektörün hâkimiyetine son verilmelidir. Kentsel dönüşüm projeleri, yoksulların toplumsal, mekânsal, ekonomik ihtiyaçları dikkate alınarak planlanmalı ve uygulanmalıdır. Dönüşüm süreci şeffaf olmall, alan gecekondu sakinleri ile birlikte tasarlanmalıdır. Konut ödemelerinin sürdürülebilir olması için gecekonduda yaşayan ve düzenli gelir sahibi olmayanlara tam istihdam sağlanmalıdır. 


\title{
Extended Abstract
}

\section{Problems That Squatter Owners May Encounter after the Implementation of Urban Transformation in Narlıdere, İzmir}

\author{
Ayça Uysal \\ ORCID: 0000-0003-4868-3739
}

Adile Arslan Avar

ORCID: 0000-0002-1548-7347

Based on the Critical Urban Theory, the study discusses the housing question of the poor against neoliberal housing production in İzmir. The problem of research is the dispossession of the poor living under the pressure of the rent gap created by neoliberal housing production. The aim of the study is to examine the situation of the poor living in the squatter housing area in İkinci İnönü Neighborhood in Narlıdere İzmir, -which was chosen as the sampling area because of being a good representation of the situation in İzmir- against the rent pressure created by the luxury housing production surrounding the squatter housing area by doing a hypothetical Housing Affordability Index (HAI) analysis.

This study is based on the findings of the master thesis completed and defended in 2019. It basically consists of two parts. In the first part, neoliberal urbanization and housing production, neoliberal policies in Turkey, urban transformation, and housing production in İzmir are examined based on the literature. In the second part, based on the findings of the field study carried out in the İkinci İnönü Neighborhood, the financialization of housing in İzmir, housing production under neoliberal policies, and the situation of the squatter housing residents against the dominant housing production are explained and HAI calculations are clarified. The fieldwork is based on qualitative and quantitative research techniques. Primary data on spatial development, neighborhood units, structural characteristics of the squatter units; and socio-economic characteristics, income level, property ownership, and infor- 
mation and preferences regarding the urban transformation project of residents of the squatter housings were collected through focus groups, face-toface in-depth interviews, and surveys.

Speculative housing production under neoliberal policies is defined by the dominance of the "exchange value" of the house over its "use value". The neoliberal macroeconomic transformations that started in the 1980s, the restructuring of the state, and the transformation of cities into capital accumulation areas have triggered each other. As mass housing and urban transformation projects become the most important means of creating and closing the rent gap, and capital accumulation, the poor are dispossessed and lose their use-value houses. The capital's anchoring in the urban area, the increase in the weight of the housing and land market in the economy, and the increase in the profit shares left to the market actors end up the exclusion of the poor from the housing market. Similar to the situation in Turkey, the increasing luxury housing production since the 1990s in Narlıdere, İzmir, the increased density and zoning rights in these planned areas, and the rapidly rising real estate prices have been creating an ever-increasing rent gap.

The case study area, which is a convenient representation of the situation in İzmir, is surrounded by luxury housing areas and creates a rent gap. The squatter housing area in the İkinci İnönü Neighborhood, which was discussed as to become an urban transformation area also at the beginning of the 2000s, was declared a risky area in 2013 with the Law No. 6306 named Transformation of Areas Under Disaster Risk. With the declaration of the squatter housing areas as risky areas, squatters which are the "use value" of the poor became open to include in the capital accumulation through transformation projects that will create "exchange value".

The process of preparing the zoning plan and urban transformation project that includes the squatter housing area in İkinci İnönü Neighborhood still continues. Therefore, there are restrictions on data sharing. Due to these limitations, the data used in this study is based on face-to-face deep interviews with Narlidere Municipality officials and documents (images) provided by them. Narlıdere Municipality has been authorized by the Ministry of Environment and Urbanization for the urban transformation project. Transformation and zoning plan studies have been carrying out with the cooperation of the Ministry and Narlidere Municipality. According to the information received from Narlıdere Municipality, the project will be performed with a private-public partnership based on a 50 percent share. The main target of the project is the middle and upper-income groups. The aim of the project is to 
conduct the process based on $100 \%$ agreement with the squatter housing residents. It has been reported that the project was submitted to the approval of the Ministry, and that the financial and approval process of the project has not been completed. The negotiations between the Ministry and the Municipality are continuing. Based on the fieldwork observations, it can be said that, although the zoning plan and transformation project that prepared within the scope of Law No. 6306 were submitted to the approval of the Ministry, the residents of the squatter housing were not informed about the project. The residents are not aware of the financial structure of the project, their rights, or losses in the project.

In the field study, household surveys and physical and spatial examinations were conducted in 60 of the 622 housing units within the study area. According to the fieldwork findings and the data in 2019, when the study was conducted, the income of approximately $72 \%$ of the households living in the area where the majority of the squatter units are in poor and moderate conditions is below the poverty level; almost all of them have income below the poverty level. HAI calculations show that it is not possible for the squatter housing residents to cover the repayments after the implementation of the project. In only one of the HAI scenarios created within the scope of the study, $5 \%$ of the households will be able to own a house. Such that, only if the land value of the squatter house they own is accepted as $50 \%$ advance payment and $50 \%$ of the household income is allocated for housing repayments, they will be able to own a house from the urban transformation project. Their ability to pay the repayments and dues is based on an extremely optimistic assumption.

The transformation project is clearly practiced as market-based and it focuses on spatial transformation. The research findings and HAI calculations that take the housing prices and household income into account show that the urban transformation process will result in slum clearance and residents of the squatters may encounter critical social, economic, and spatial questions.

\section{Kaynakça/References}

Adaman, F., Akbulut, B., ve Arsel, M. (2017). Neoliberal Turkey and its discontents: Economic policy and the environment under Erdogan. Bloomsbury Publishing.

Arkon, C., Özdemir, S., ve Serim, E. (2010). İkinci İnönü ve Atatürk Mahalleleri 1/1000 ölçekli revizyon planı uzman görüşü raporu.

Arslan, H. (2013). Kentsel dönüşüm ve sosyal dışlanma: Narlıdere kentsel yenileme projesinin sosyal dışlanma ekseninde incelenmesi. Sosyoloji Araşttrmaları Dergisi, 16(1), $1-45$. 
Ataöv, A. ve Osmay, S. (2007). Türkiye'de kentsel dönüşüme yöntemsel bir yaklaşım. Metu Jfa, 2, 57.

Atasoy, Y. (2017). Repossession, re-informalization and dispossession: The 'Muddy Terrain' of land commodification in Turkey. Journal of Agrarian Change, 17(4), 657-679.

Baker, E., Mason, K. ve Bentley, R. (2015). Measuring housing affordability: A longitudinal approach. Urban Policy and Research, 33(3), 275-290. doi: 10.1080/08111146.2015.1034853

Brenner, N. ve Theodore, N. (2002). Cities and the geographies of "Actually Existing Neoliberalism". Antipode, 34(3), 349-379.

Brenner, N., Peck, J. ve Theodore, N. (2010). Variegated neoliberalization: geographies, modalities, pathways. Global Networks, 10(2), 182-222.

Çelik, Ö. ve Gough, J. (2014). Introduction to the special section: Urban neoliberalism, strategies for urban struggles, and 'The Right to the City'. Capital and Class, 38(2), 414451.

Çelik, H. Z., Çilingir T. (2017). Parsel bazındaki dönüşüm uygulamalarının kentsel maliyetleri, Karşıyaka-Bostanlı Mahallesi örneği. Planlama Dergisi, 27(3), 329-346.

Çelikbilek, A. ve Öztürk, Ş. M. Ç. (2017). 6306 sayılı kanun kapsamında yürütülen kentsel dönüşüm çalışmaları ve İzmir uygulamaları. Medeniyet Sanat Dergisi, 3(2), 187213.

Demirtas-Milz, N. (2013). The regime of informality in neoliberal times in Turkey: The case of the Kadifekale urban transformation project. International Journal of Urban and Regional Research, 37(2), 689-714.

Emlak Kulisi, 26 Temmuz 2020 tarihli haber, son erişim tarihi: 19.04.2021:

https://emlakkulisi.com/izmir-narliderede-kentsel-donusum-icin-dugmeye-basildi/644435

Eranıl Demirli, M., Tuna Ultav, Z. ve Demirtaş-Milz, N. (2015). A socio-spatial analysis of urban transformation at a neighborhood scale: The case of the relocation of Kadifekale inhabitants to TOKİ Uzundere in İzmir. Cities, 48, 140-159.

Eraydın, A. vd. (2013). Büzülen kentlerin yeniden canlandırılmasına yönelik bilgi ve strateji oluşturulmasına katkı: İzmir kent bölgesinde yayılma, yığılma, küçülme ve büzülme süreçlerinin birlikteliği ile ortaya çıkan yeni mekansal örüntülerin Avrupa kentleri ile karşılaştırılması. Proje No: 109K590, TÜBİTAK.

Erman, T. (2016), Formalization by the state, re-informalization by the people: A gecekondu transformation housing estate as site of multiple discrepancies. International Journal of Urban and Regional Research, 40(2), 425-440.

Evrensel Gazetesi, 19 Ağustos 2020 tarihli haber, son erişim tarihi: 19.04.2021:

https://www.evrensel.net/haber/411903/narlideredeki-kentsel-donusum-projesindenhalk-sikayetci-mesele-dort-duvar-degil

Evrensel Gazetesi, 18 Ocak 2021 tarihli haber, son erişim tarihi: 19.04.2021: https://www.evrensel.net/haber/423850/narlidere-halki-kentsel-donusum-surecinemudahil-olmak-istiyor 
Forrest, R. (2008). Globalization and the housing asset rich: Geographies, demographies and policy convoys. Global Social Policy, 8(2), 167-187.

Fraser, J. C. ve Kick, E. L. (2014). Governing urban restructuring with city-building nonprofits. Environment and Planning A, 46(6), 1445-1461.

Genç, F. N. (2014). Gecekonduyla mücadeleden kentsel dönüşüme Türkiye'de kentleşme politikaları. Adnan Menderes Üniversitesi Sosyal Bilimler Enstitüsü Dergisi, 1(1), 15-30.

Goldman, M. (2011). Speculative urbanism and the making of the next world city. International Journal of Urban and Regional Research, 35(3), 555-581. doi: 10.1111/j.14682427.2010.01001.x

Hancock, K. E. (1993), 'Can pay? Won't pay?' or 'Economic principles of'affordability'. Urban Studies, 30(1), 127-145. doi: 10.1080/00420989320080081

Harvey, D. (2005). A brief history of urbanism. Oxford University Press.

Harvey, D. (2006). Neo-liberalism as creative destruction. Human Geography, 88(2), 145158.

Jessop, B. (2002). Liberalism, neoliberalism, and urban governance: A state-theoretical perspective. Antipode, 34(3), 452-472.

Karasu, M. A. (2005). Türkiye' de konut sorununun çözümünde farklı bir yaklaşım; Belediye-Toplu Konut İdaresi-Konut Kooperatifleri İşbirliği Modeli. AİBÜ-İ̈BF Ekonomik ve Sosyal Araştırmalar Dergisi, 1, 56-87.

Kılıç, E. M. ve Göksu, A. E. (2018). Bir kentsel dönüşüm deneyimi: Kadifekale-Uzundere ikileminde bireysel öyküler üzerine düşünmek. Planlama Dergisi, 28(2), 201-217.

Kutty, N. K. (2005). A new measure of housing affordability: Estimates and analytical results. Housing Policy Debate, 16(1), 113-142. doi: 10.1080/10511482.2005.9521536

Kuyucu, T. (2017). Two crises, two trajectories: The impact of the 2001 and 2008 economic crises on urban governance in Turkey. F. Adaman, B. Akbulut ve M. Arsel (Der.), Neoliberal Turkey and its discontents: Economic policy and the environment under Erdogan içinde (s. 44-76). I.B. Tauris, London.

Kuyucu, T. ve Ünsal, Ö. (2010). 'Urban transformation' as state-led property transfer: An analysis of two cases of urban renewal in Istanbul. Urban Studies, 47(7), 1479-1499.

Linneman, P. D. ve Megbolugbe, I. F. (1992). Housing affordability: myth or reality?. Urban Studies, 29(3-4), 369-392. doi: 10.1080/00420989220080491

Marcuse, P. ve Madden, D. (2016). In defense of housing. London, New York: Verso.

Mayer, M. (2009). The 'right to the city' in the context of shifting mottos of urban social movements. City, 13(2-3), 362-374. doi: 10.1080/13604810902982755

McCarthy, J. (2004). Privatizing conditions of production: Trade agreements as neoliberal environmental governance. Geoforum, 35(3), 327-341.

Özdemir, S. vd. (2005). İmar afları sonrasında İzmir'de gecekondulaşma sosyo-ekonomik, mekansal bir çözümleme, İzmir. Proje No: SBB8005, TÜBİTAK.

Özdemir, D. (2011). The role of the public sector in the provision of housing supply in Turkey, 1950-2009. International Journal of Urban and Regional Research, 35(6), 10991117. doi: 10.1111/j.1468-2427.2010.00974.x 
Padley, M. ve Marshall, L. (2019). Defining and measuring housing affordability using the minimum income standard. Housing Studies, 34(8), 1307-1329.

Peck, J., ve Tickell, A. (2002). Neoliberalizing space. Antipode, 34(3), 380-404.

Stone, M. E. (2006). What is housing affordability? The case for the residual income approach. Housing Policy Debate, 17(1), 151-184. doi: 10.1080/10511482.2006.9521564

Saraçoğlu, C. ve Demirtaş-Milz, N. (2014). Disasters as an ideological strategy for governing neoliberal urban transformation in Turkey: Insights from İzmir/Kadifekale. Disasters, 38(1), 178-201. doi:10.1111/disa.12038

Tekeli, İ. (2009). Türkiye'de Cumhuriyet Döneminde kentsel gelişme ve kent planlaması, Y. Sey (Der.), 75 Yılda Değişen Kent ve Mimarlık içinde (s. 106-134). Türk Tarih Vakfı Yayınları, İstanbul.

Topal, A., Yalman, G. ve Çelik, Ö. (2019). Changing modalities of urban redevelopment and housing finance in Turkey: Three mass housing projects in Ankara. Journal of Urban Affairs, 41(5), 630-653. doi: 10.1080/07352166.2018.1533378

Türkiye Cumhuriyeti Resmi Gazete. 2012, 31 Mayıs.

Türk-İş (2009). Mart Ayı Yoksulluk Raporu. 17 Nisan 2019 tarihinde http://www.teksif.org.tr/mart-2019-aclik-ve-yoksulluk-siniri-2014-10-tl_icerik_10248-1.html adresinden erişildi.

Türkün, A. (2014). Mülk, mahal, insan: İstanbul' da kentsel dönüşüm (Property, Site, Human Being: Urban Regeneration in İstanbul), İstanbul: Bilgi Üniversitesi.

Türkün, A. (2015). Ruthless transformation efforts in the housing areas of the urban poor and implications for the right to housing.

Waite, I. A. (2016). Planning, power, politics: Urban redevelopment in Istanbul. (Doktora tezi). https://escholarship.org/uc/item/04f489ff

Yetişkul, E. (2018). İzmir modeli kentsel dönüşüm uygulamaları, İ. Tekeli (Der.), İzmir modeli çalışmaları dördüncü kitap: İzmir Büyükşehir Belediyesinin fiziki planlama yaklaşımları içinde (s. 56-89).

Ziraat Bankası (2019). Kredi Hesaplama Aracı, 20 Nisan 2019 tarihinde https://www.ziraatbank.com.tr/tr/hesaplama-araclari/kredi-hesaplama/konut-kredisi adresinden erişilmiştir. 